\title{
The multidisciplinary management of rectal cancer
}

Deborah S. Keller ${ }^{1}$, Mariana Berho ${ }^{2}$, Rodrigo O. Perez ${ }^{3}$, Steven D. Wexner ${ }^{4}$, Manish Chand $^{5 *}$

${ }^{1}$ Department of Surgery, New York-Presbyterian, Columbia University Medical Centre, New York, USA

${ }^{2}$ Department of Pathology and Laboratory Medicine, Cleveland Clinic Florida, Weston, Florida, USA

${ }^{3}$ Angelita \& Joaquim Institute, São Paulo, Brazil

${ }^{4}$ Department of Colorectal Surgery, Cleveland Clinic Florida, Weston, Florida, USA

${ }^{5}$ Wellcome EPSRC Centre for Interventional and Surgical Sciences (WEISS);

University College London, London, UK

*Email: $\underline{\text { m.chand@ucl.ac.uk }}$ 
Abstract | Rectal cancer treatment has evolved during the past 40 years with the use of a standardised surgical technique for tumour resection: total mesorectal excision. A dramatic reduction in local recurrence rates and improved survival outcomes were consequences of a better understanding of the surgical oncology of rectal cancer, and the advent of adjuvant and neoadjuvant treatments to compliment surgery paved the way for a multidisciplinary approach to disease management. Further improvements in imaging techniques and the ability to identify prognostic factors, such as tumour regression, extramural venous invasion, and threatened margins, introduced the concept of decision-making based on preoperative staging information. Modern treatment strategies are underpinned by accurate high-resolution imaging guiding both neoadjuvant therapy and precision surgery, followed by meticulous pathological scrutiny identifying the important prognostic factors for adjuvant chemotherapy. Included in these strategies are organ-sparing approaches and watch-and-wait strategies in appropriate patients. These pathways rely on close working of interlinked disciplines within the multidisciplinary team. Such multidisciplinary forums are becoming standard in the treatment of rectal cancer across the UK, Europe, and more recently, the USA. This Review examines the essential components of modern-day management of rectal cancer through a multidisciplinary team approach, providing information that is essential for any practising colorectal surgeon to guide the best patient care. 
Key Points:

- As rectal cancer treatment becomes more precise, high-resolution imaging techniques have been established to identify important tumour characteristics that help guide management.

- High-resolution magnetic resonance imaging scans are increasingly dictating treatment strategies by providing predictive and prognostic information related to the tumour, and are a standard part of the patient investigation pathway.

- Surgical management depends on patient and tumour factors with an aim to optimise function and survival with the lowest risk of recurrence.

- Multiple approaches are currently available for resection, including radical surgery involving excision of the rectum and associated mesentery and organsparing techniques involving local excision of the lesion or deferring surgery altogether.

- The pathological assessment of the resected rectal cancer specimen provides a level of quality control ensuring that surgical principles have been adhered to and that the surgery was performed in an optimal oncological manner.

- Multidisciplinary team presentation of imaging data, evidence-based oncological, surgical and functional recommendations, in addition to pathological assessment of surgical quality, is an essential part of formalised cancer care. 


\section{[H1] Introduction}

Colorectal cancer is the third most common cancer and the second leading cause of cancer death globally, with rectal cancer accounting for one third of these cases ${ }^{1}$. Although there is an overall trend of decreased incidence and mortality from colorectal cancer, the incidence of rectal cancer in patients younger than 50 years has been exponentially increasing, with rates estimated to rise $124.2 \%$ for patients 20 to 34 years of age by 2030 in the United States ${ }^{2,3}$ (FIG. $1^{4}$ ); similar trends are seen in Europe $^{5}$. In all patients, rectal cancer has a substantial physical, emotional and financial burden. The treatment of rectal cancer is evolving, and determining the ideal treatment plan is a multifaceted process that requires consideration of patient preferences, tumour characteristics, intent of the surgery and functional outcomes. Appropriate patient selection with respect to surgical treatment options and the use of multimodality therapy could substantially affect recurrence and survival. Traditionally, using the tumour-node-metastasis (TNM) staging system, locally advanced disease - T3-4, node-negative (N0) or node-positive disease without distant metastasis (N1-2M0) — was recommended to undergo neoadjuvant chemoradiotherapy and adjuvant chemotherapy to reduce the risk of locoregional recurrence. However, tumour behaviour, biomarkers and regional differences in the use of neoadjuvant and adjuvant therapies are now considered when recommending therapy. Several landmark trials established the dose, timing and outcomes of radiotherapy and chemotherapy in the treatment algorithm for rectal cancer (Table 1)

The need for, and optimal timing of, surgical resection after neoadjuvant treatment continue to evolve. As tumour regression seems to be a time-dependent phenomenon, initial data provided by retrospective series suggested that longer interval periods 
would lead to greater probability of achieving a complete pathological response $\mathrm{e}^{6,7}$. However, prospective randomised trials have failed to provide evidence for routinely delaying definitive surgery at the cost of a potentially worse surgical specimen, commonly credited to the scarring or fibrotic effects of radiation ${ }^{8,9}$. The treatment strategies for planning care or timing for the best oncological and functional outcomes are underpinned by accurate high-resolution imaging, guiding both neoadjuvant therapy and precision surgery, followed by meticulous pathological assessment. With advances in prediction and prognostication of treatment response and oncological outcomes, the multidisciplinary team (MDT) has great potential to guide the treatment plan using all data, images and expert opinion. In this Review, we aim to provide an overview of modern rectal cancer management, with a focus on the effect of the MDT and the elements used for staging and developing the treatment plan.

\section{[H1] Using MRI to guide treatment}

As rectal cancer treatment becomes more precise, high-resolution imaging techniques help to identify important tumour characteristics, which then determine management strategies. Since its initial recommendation to be included in the assessment of rectal cancer over the past decade ${ }^{10,11}$, MRI scans are increasingly dictating treatment strategies by providing predictive and prognostic information related to the tumour, and now form a standard part of the patient investigation pathway. An example of how MRI can be used to guide treatment by the MDT is seen in FIG 2.

High-resolution imaging has taken an increasingly central role in treatment decisionmaking in rectal cancer. Much of the complexity of rectal cancer surgery and the factors that determine use of oncological therapy and potentially predict outcomes can 
be identified with great clarity and reproducibility on MRI and CT imaging. These two modalities are able to stage local and distant disease, respectively. This Review will concentrate on local staging and the importance of MRI in treatment planning. The information obtained during local staging serves both surgical and oncological treatment planning.

\section{[H2] Threatened circumferential resection margin.}

The most important factor in determining the risk of local recurrence and the need for neoadjuvant treatment is the proximity of the tumour to the mesorectal fascia (MRF), which forms the outermost boundary of the mesorectum. It has been shown that tumours (including a mesorectal tumour deposit or a metastatic lymph node) within 1 $\mathrm{mm}$ of the MRF on preoperative imaging are associated with a substantially increased risk of local recurrence, constituting a threatened circumferential resection margin $(\mathrm{CRM})^{12}$ (FIG. 3a). As the accuracy of MRI has improved with a better understanding of a standardised imaging protocol ${ }^{13}$, this level of detail can be seen on T2-weighted images (T2WI MRI) ${ }^{14}$. Identifying a tumour within $1 \mathrm{~mm}$ of the MRF on MRI is an indication for neoadjuvant long-course chemoradiation if curative resection is planned $^{15}$

\section{[H2] T3 sub-stage and T4 tumours.}

A tumour close to the MRF must be differentiated from the extent of tumour penetration into the mesorectum and anatomically adjacent organs (FIG. 3b). These findings are conceptually and prognostically separate entities. The mesorectum varies in its extent along the length of the rectum. Tumour penetration into the mesorectum is a sub-classification of the T-staging system, referred to as T3 sub-stage. Willett, 
Hermanek and Merkel were amongst the first to show the prognostic heterogeneity of T3 tumours ${ }^{16-18}$, which can be accurately seen on T2WI MRI ${ }^{19}$. This method has led to the selective use of chemoradiotherapy based on T3 sub-stage, as not all T3 tumours are associated with poor prognosis. T3a/b tumours $(<5 \mathrm{~mm}$ penetration beyond the muscularis propria) are 'good prognosis' tumours and need not be subjected to chemoradiotherapy in the absence of other risk factors, such as positive nodes, extramural venous invasion or lymphovascular invasion. T3c or T3d tumours (5-15 $\mathrm{mm}$ or $>15 \mathrm{~mm}$ beyond muscularis propria, respectively) are considered 'poor prognosis' tumours and should be irradiated in a long-course chemoradiotherapy regime $^{10,11}$. The other distinction from a threatened CRM is invasion into the surrounding structures, such as pelvic wall, vagina, prostate, bladder or seminal vesicles, as seen in T4b tumours. These tumours might be considered for more radical surgery involving en-bloc resection of more than just the rectum. Invariably, these tumours will need neoadjuvant treatment but accurate imaging and understanding the extent of disease through a compartment-based grading system can help determine the optimal strategy ${ }^{20,21}$.

\section{[H2] Differentiating cT3a versus cT2 tumours.}

Distinguishing between T2 and early T3 (cT3a) rectal cancers can be challenging with MRI. However, experts will agree that such differentiation is irrelevant from a practical standpoint. Studies have shown that patients with T3a and T2 rectal cancers showed very similar 5-year overall survival when either lymph node negative $(91.2 \%$ versus $93.6 \%$, respectively) or lymph node positive $(77.8 \%$ versus $82.8 \%$, respectively $)^{16}$. T2 and early $\mathrm{T} 3$ cancers rarely threaten the CRM and usually constitute good candidates for total mesorectal excision (TME) alone, provided there 
are no additional risk factors. Data are evolving that suggest that T2 cancers might behave differently from cT3 (including cT3a) lesions in terms of response to neoadjuvant chemoradiation. Studies on patients who obtain a complete clinical response after neoadjuvant chemoradiotherapy show that increasing cT stage was associated with increased risk of local regrowth (random-effects hazard ratio per cT stage: $1 \cdot 40,95 \% \mathrm{CI}: 1 \cdot 00-1 \cdot 94 ; P=0 \cdot 048) .2$-year cumulative incidence of local regrowth was $19 \%$ (95\% CI: 13-28) for stage cT2 tumours and 31\% (95\% CI: 26-37) for cT3 tumours ${ }^{22}$. Local recurrence-free survival has also been shown to be significantly better for patients with cT2 tumours than those with cT3 tumours at 1 year after neoadjuvant chemoradiotherapy (96\% versus 69\%; $P=0.009)$, with a lower baseline $\mathrm{T}$ stage serving as an independent predictor of improved local recurrencefree survival at 1 year $(\mathrm{OR}=0.0995 \% \mathrm{CI}: 0.01-0.81 ; P=0.03)^{23}$. Such differentiation might become clinically relevant for the purpose of multidisciplinary discussion when tumour response is anticipated and relevant for the decision management process.

\section{[H2] Extramural venous invasion.}

The observation that venous invasion with rectal cancer is associated with poor prognosis dates back to the $1930 \mathrm{~s}^{24}$; however, with the lack of a standardized definition of venous or vascular invasion, venous invasion has only become an accepted marker of poor prognosis in the past 5 years. Talbot first described the important distinction between large and small vessel disease in rectal cancer ${ }^{25}$, which can be seen with great accuracy on T2WI MRI ${ }^{26,27}$. The importance of MRI-detected extramural venous invasion (EMVI) is now well established; poor disease-free survival outcomes and even an increased risk of local recurrence have been reported when EMVI is seen on baseline staging or reassessment scans ${ }^{26,28}$. EMVI can 
potentially be used as an imaging biomarker and regression of large-vessel disease is correlated with reduced risk of recurrence ${ }^{29}$. Perhaps the importance of EMVI is most marked in stratifying T2 tumours that would benefit from adjuvant chemotherapy versus intensified neoadjuvant treatment regimes in resistant tumours ${ }^{30,31}$. Figure 4 shows an example of EMVI.

\section{[H2] Nodal disease.}

Nodal disease is associated with a risk of disease recurrence but the risk profile has changed due to modern surgery and the risk is now associated with distant disease rather than local failure ${ }^{32,33}$. MRI is the optimal modality for identifying nodal disease using signal heterogeneity and irregular borders to predict tumour infiltration ${ }^{34}$. Yet even in the most capable hands, sensitivity and specificity is not ideal. The importance of mesorectal nodes is often overstated and, in reality, staging nodal disease might not be as important as it first seems as nodal status is less relevant for guiding treatment plans. Pretreatment, sub-centimetre nodes cannot be wellcharacterised on T2WI MRI and overtreatment should be avoided, but patients with $\mathrm{N} 2$ disease (metastasis in four or more regional lymph nodes) often have large, obvious nodes and their appearance on MRI will influence treatment choice regarding the limitations of the surgical resection, chemotherapy used and timing. Nodal disease remains a concern for local recurrence and some centres routinely offer neoadjuvant chemoradiotherapy to patients with N1 disease. This approach is based on historical data, and might subject patients to a morbid treatment with little, if any, advantage if a proper TME surgery is performed. The MRC-CR07 trial demonstrated that when the plane of surgery is complete, there is little benefit for neoadjuvant treatment for nodal disease alone ${ }^{35}$. Thus, malignant nodes within the surgical 
specimen are another reason for offering adjuvant chemotherapy to mitigate the risk of distant disease recurrence. However, there are regional differences in use of chemotherapy for node positive disease and enthusiasm has developed for delivering the chemotherapy in a neoadjuvant rather than adjuvant setting ${ }^{36}$.

\section{[H1] Neoadjuvant treatment}

Once the treatment decision is made for a patient with rectal cancer to have neoadjuvant therapy, three evidence-based approaches are currently supported: longcourse chemoradiotherapy; induction chemotherapy followed by long-course chemoradiotherapy; and short-course radiotherapy with increasing use of regimens where all chemotherapy is delivered upfront (total neoadjuvant treatment) and consolidation approaches (delivering chemotherapy after chemoradiotherapy completion and before surgery) ${ }^{10,11,36-38}$. The choice of treatment depends on the tumour prognosis, regional preferences, patient fitness and MDT decision. Longcourse chemoradiotherapy delivers 45-50 Gy of external-beam, intensity-modulated radiation therapy over 25 to 28 daily fractions, with concomitant radiation-sensitizing fluoropyrimidine-based chemotherapy, such as oral capecitabine, continuous infusion 5-fluorouracil or bolus 5-fluorouracil with leucovorin. Short-course radiotherapy aims to sterilize the mesorectal fat before surgery and the regimen does not include chemotherapy. Patients receive 5 Gy per day for 5 days total, then typically proceed to surgery within 1-2 weeks. Short-course radiotherapy has been shown to be noninferior to traditional long-course chemoradiotherapy in relation to 3-year local recurrence, distant recurrence, relapse-free survival, overall survival or late toxicity in T3N0-2M0 rectal adenocarcinoma within $12 \mathrm{~cm}$ from anal verge ${ }^{39}$. Long-course chemoradiotherapy might be more effective in reducing local recurrence for distal 
tumors, and is more appropriate for $\mathrm{T} 4$ tumors and those threatening the anal sphincters than short-course chemoradiotherapy because of the time needed for downsizing before surgery ${ }^{40,41}$. Induction chemotherapy or total neoadjuvant therapy (TNT) regimens use upfront combination chemotherapy with 5-fluorouracil (or capecitabine), oxaliplatin, and leucovorin for 3-6 cycles before the proceeding longcourse radiotherapy. This approach offers early systemic control, helps avoid postoperative chemotherapy-related toxicity and improves completion rates by delivering the therapy before surgery when the patients are most fit and compliant 41,42. Studies show that TNT has similar oncological outcomes to postoperative chemotherapy, facilitates delivery of planned systemic therapy and nonoperative treatment strategies aimed at organ preservation, and is more cost-effective ${ }^{36,42,43}$. Long-term recurrence and survival outcomes data with TNT are pending.

\section{[H2] Reassessment after neoadjuvant treatment.}

The standard for reassessing disease after neoadjuvant treatment and the role of MRI has not yet been fully defined. Perceived difficulty in interpretation of images following the fibrotic effects of radiotherapy has affected the utility of T2WI MRI as a useful assessor of treatment response. There are several reports of good correlation with pathology, but these studies reflect outcomes at high-volume expert centres, where results are not globally reproducible. ${ }^{14,44,45}$. As more novel MRI derivatives using innovative sequences are developed, such as Diffusion Weighted Imaging (DWI), interpretation of response to treatment might become more objective ${ }^{46}$. Another concern is that reassessment might be a redundant exercise, as the treatment strategy is infrequently changed. However, this argument ignores the precious prognostic and predictive information available from MRI, which could be obtained 
from reassessment and might potentially help shape future guidelines. It also deprives the patient from knowing whether they are in the $20 \%$ of patients who have had a complete response from neoadjuvant treatment. These patients might be able to avoid surgery altogether ${ }^{47-49}$.

There has been a paradigm shift in planning the best interval between long-course neoadjuvant therapy and surgery. Traditional thinking relied on a waiting period of $8-$ 12 weeks for optimal downstaging of the disease and complete clinical response ${ }^{40}$. However, the radiation-associated fibrosis from extended waiting periods prior to surgery (>8 weeks) creates a technically more challenging operation with a worse TME specimen, contributing to reduced rates of sphincter preservation and increased postoperative morbidity ${ }^{9,41}$. Although there is a lack of consensus from current practice guidelines, the evidence currently supports surgery 5-12 weeks following the completion of long-course chemoradiotherapy ${ }^{50}$. An algorithm of an example of the MDT discussion is seen in FIG 5.

\section{[H1] Surgical options}

Surgical management depends on patient and tumour factors with an aim to optimise function and survival with the lowest risk of recurrence. The clinical assessment of rectal cancer from physical exam by a colorectal surgeon is essential in determining the treatment scheme, including noting the location, mobility, proximity to sphincter, and condition of pelvic floor. With this baseline information, multiple tools are currently available for resection, with ongoing research on new minimally invasive and non-operative approaches. The main schools of thought are radical surgery involving excision of the rectum and associated mesentery, and organ-sparing or 
preservation techniques involving local excision of the lesion or deferring surgery altogether.

\section{[H2] Radical surgical approaches.}

The primary goal of rectal cancer surgery is to achieve complete excision of the tumour and surrounding mesorectum with a tumour-free margin, termed R0 resection. This end point has been proven to have the greatest effect on recurrence and overall survival ${ }^{35}$. TME, in which the primary tumour is resected along the embryological fascial planes with all associated lymphatics, remains the gold standard for curative resection, decreasing local recurrence rates and improving survival ${ }^{51}$ (FIG 6). In patients in whom a restorative procedure is not possible owing to tumour location, invasion or involvement of the sphincter complex that may impair continence, an abdominoperineal resection might be the best surgical option. In the absence of these features, sphincter preservation with a restorative proctectomy is usually feasible. In restorative proctectomy, a defunctioning stoma has been recommended to reduce the morbidity associated with an anastomotic leak rate, especially in patients undergoing low rectal cancer surgery, in whom limited reconstructive options exist and a leak could have a devastating short-term medical and longer term functional and oncological effects ${ }^{52}$. However, there are risks associated with a temporary stoma, including dehydration, renal failure, inability to reverse the stoma, as well as risks from the stoma reversal procedure ${ }^{53,54}$. Nonetheless, stomas can protect patients with a colorectal or coloanal anastomosis from postoperative sepsis, reduce delays to adjuvant chemotherapy, decrease the need for reoperation to repair an anastomotic leak and might even decrease the anastomotic leak rate ${ }^{55,56}$. 
Several options are available for resection, including open, laparoscopic, hand assisted, robotic and transanal approaches (FIG. 7). Laparoscopic surgery was introduced in the early 1990s, and despite early concerns, oncologic equivalency and short-term clinical benefits over open surgery have been reported for rectal cancer ${ }^{35,57,58}$. Reported outcomes with a TME were improved in both open and minimally invasive approaches ${ }^{35,59-63}$. Preliminary results from the ACOSOG Z6051 (240 laparoscopic surgeries and 222 open surgeries) and ALaCaRT (194 laparoscopic surgeries and 208 open surgeries) trials questioned the oncological equivalence of the laparoscopic approach for rectal cancer ${ }^{64,65}$. Results from these key trials are shown in Table 2 and Table 3. These reports were not intended to be a moratorium for laparoscopic rectal cancer ${ }^{66}$; however, they have focused attention on other surgical options, such as robotic and transanal approaches. Fortunately the longer term reports found no statistically significant differences in oncologic outcomes between laparotomy and laparoscopy ${ }^{67,68}$. With laparoscopy, there are anatomical, technical and visual limitations. Robotic assisted surgery was introduced to address these limitations, and results have suggested comparable oncologic outcomes, but with longer operative times and higher costs ${ }^{69-71}$. The randomized controlled multicentre international ROLARR trial found no oncological differences between robotic and laparoscopic TME in 466 patients $^{71}$. Thus, the MDT needs to weigh the costs and benefits for the robotic approach in rectal cancer resections.

The transanal TME (TaTME) is the newest minimally invasive approach, combining a minimally invasive abdominal TME with a transanal endoscopic resection ${ }^{72}$. Under endoscopic visualisation, the rectum is circumferentially mobilised and the dissection continued proximally in the avascular TME plane towards the peritoneal reflection, 
meeting the abdominal mobilisation. Since inception in 2010, this 'bottom up' approach, in which the resection incorporates procedures through both an abdominal and transanal approach, has proven safe and feasible, with theoretical advantages of access and visualisation in the most challenging portion of a proctectomy, which could make this technique the gold standard for low rectal cancer resection ${ }^{73-75}$. Many publications have demonstrated its safety, feasibility and short-term oncological acceptability ${ }^{74-81}$. An international registry, controlled trials and standardised training programs are underway for further outcomes and safe expansion of this technique ${ }^{82-84}$.

\section{[H2] Organ sparing approaches.}

Local transanal excision might be an option for highly selected patients with small $(<3 \mathrm{~cm})$, low (within $8 \mathrm{~cm}$ of the anal verge) and well-to-moderately differentiated rectal tumours that are limited to $<30 \%$ of the lumen and with no evidence of nodal involvement ${ }^{41}$. Transanal endoscopic surgery (TES) platforms, such as transanal minimally invasive surgery (TAMIS), transanal endoscopic microsurgery (TEM), and transanal endoscopic operation (TEO), furthered the ability to perform a complete resection with negative microscopic margins, a reduced rate of specimen fragmentation and lower recurrence rates than traditional transanal excisions ${ }^{85,86}$. However, there is no lymphadenectomy with local excision or TES platforms. Thus, the substantial reduction in morbidity with local excision must be balanced against the possible risks of positive resection margins, locoregional recurrence and lower overall survival compared to an abdominal resection with TME ${ }^{87-89}$. Rectal cancer recurrence rates after local resection alone were reported in 10\% (range, 0-24) of T1 cancers, $25 \%$ (range, 0-67) of T2 cancers and 38\% (range, 0-100) of T3 cancers, with risk of retained lymph node metastasis up to $25 \%$ in $\mathrm{T} 2$ lesions ${ }^{90,91}$. Thus, current 
recommendations for local excision are for benign and early (T1) rectal lesions, unless the procedure is being performed within a clinical trial ${ }^{41}$. A multicentre study of 62 patients who received short-course radiotherapy followed by TEM 8-10 weeks later in patients with clinical T1-2N0 rectal cancer was effective in the majority of patients considered high-risk or who refused TME surgery ${ }^{92}$. Initial results from trials using conventional neoadjuvant chemoradiotherapy followed by local excision with a TES platform reported good overall oncological and survival outcomes ${ }^{93}$. Longer term follow-up using neoadjuvant chemoradiotherapy and local excision for clinically staged T2N0 advanced rectal cancers (ACOSOG Z6041) showed lower than anticipated 3-year disease-free survival $(88.2 \%$ for the intention-to-treat group and $86.9 \%$ for the per-protocol group) ${ }^{94}$. For patients with T2 and T3 cancers and with a good clinical response to neoadjuvant chemotherapy, the GRECCAR 2 trial failed to show superiority of local excision over TME, with many patients in the local excision group undergoing a completion $\mathrm{TME}^{95}$. Further studies on local excision after neoadjuvant chemoradiotherapy are underway, and local excision in carefully selected patients who refuse, or are not candidates for, the gold standard resection remain an option to discuss in MDT.

\section{[H2] Complete clinical response and watch and wait strategy.}

The effects of chemotherapy and radiation can have a substantial effect on tumour cell death in rectal cancer. These effects have introduced a new option for patients with complete eradication of the primary tumour. Such patients, who have complete pathological response after treatment, led surgeons to challenge the role of any

surgery in this setting ${ }^{47}$. The possibility that radical surgery could have been unnecessary (and potentially harmful) to these patients led Habr-Gama and colleagues 
to consider an assessment of tumour response prior to definitive surgery and the identification of patients with clinical evidence of no residual cancer (complete clinical response $)^{48}$. Select patients with complete clinical response were offered no immediate surgery and enrolled in a strict follow-up program known as 'watch-andwait'.

Habr-Gama's group have extensively published the results of the watch-and-wait approach, in which the patient undergoes regimented monitoring over 2 years rather than surgical resection in situations of a complete clinical response $e^{47-49}$. The landmark study that disrupted the surgical community was the observation that patients with complete clinical response managed non-operatively had similar oncological outcomes to patients with complete pathological response managed by radical surgery ${ }^{47}$. Additional work by Martens et al. supported the oncological and functional results of the watch-and-wait approach, showing a 3-year overall survival of $97 \%$, distant metastasis-free survival of $97 \%$, local regrowth-free survival of $85 \%$, diseasefree survival of $81 \%$, colostomy-free survival of $95 \%$ and good continence in 100 patients over a median follow-up of 41.1 months ${ }^{96}$. Additional published analyses have further confirmed these observations and provided more robust numbers to support these initial findings $s^{22,97-100}$. Despite inherent differences between multiple institutions related to the exact management of these patients, oncological outcomes seem to be equivalent across different centres, suggesting that outcomes in highly specialised and dedicated centres are reproducible ${ }^{22}$. Furthermore, an international registry created to gather and study information on these patients has reported the outcomes on nearly 1,000 patients with this approach with very similar results ${ }^{101}$. 
Patients with initial apparent complete clinical response might still develop local recurrence in nearly $25 \%$ of the cases ${ }^{22,101}$. Most of these recurrences are endoluminal and usually amenable to salvage surgery with no apparent oncological compromise from delayed definitive surgical resection ${ }^{96,102}$. Several studies discuss the concept of 'accidental' watch-and-wait, in which patients that underwent neoadjuvant treatment developed a complete clinical response. This finding is an important variable to be included in the MDT discussion once the decision has been made for the use of neoadjuvant treatment. The possibility that these patients will achieve a complete clinical response might have a substantial effect on their definitive management, patient counselling and follow-up strategies.

There is now also the concept of 'intentional' watch-and-wait, where patients with early-stage (cT2N0 rectal cancer) distal rectal cancers undergo neoadjuvant chemoradiotherapy for the purpose of avoiding radical surgery and entering the organ-preservation pathway ${ }^{49}$. In contrast to accidental organ-preservation after chemoradiotherapy, intentional watch-and-wait raises even more questions regarding the multidisciplinary discussion, such as the acceptable risk for the patient, the possibility that a viable tumour is still present, and the ideal methods and time intervals to perform surveillance. Once the purpose of neoadjuvant treatment is defined (for example, for pre-operative therapy, accidental watch-and-wait in cases where the tumour has a complete clinical response, or intentional watch-and-wait), achieving a complete clinical response, identifying features that might maximise the response, and prolonging intervals before reassessment become relevant even in the setting of early stage disease ${ }^{38,103,104}$. 
At this time, the watch-and-wait approach in the setting of complete clinical response is not a universally accepted standard of care ${ }^{105}$. In addition, although practising centres assert strict selection criteria and close follow-up, there is no current standard for selecting and monitoring patients on watch-and-wait protocols. One study suggested clinical assessment with digital rectal exam and endoscopy are the most accurate methods for identification of complete clinical response after chemoradiotherapy, with high-resolution MRI improving the diagnostic performance, and for the combination to be recommended as the optimal strategy for patient selection ${ }^{106}$. An in-depth understanding of the risks and benefits by the patient, as well close collaboration between the MDT members, imaging, endoscopy and physical exam are crucial to make this treatment safe. Although organ-preserving strategies might be a feasible option in patients with rectal cancer with complete clinical response after neoadjuvant chemoradiotherapy and included in international guidelines, further prospective trials, tracking of long-term outcomes and standardised protocols are all required before such a strategy can be widely implemented ${ }^{107,108} 109$.

\section{[H1] The pathologists role in the MDT}

The pathologist is a crucial member of the MDT, and it is essential for the colorectal surgeon to understand their unique contributions. The pathologist reports on the preoperative staging (compared with final pathology) and cancer stage after surgery, as well as the surgical performance from the margin status and specimen quality. From this evaluation, the pathologist verifies if the surgery has been performed in an optimal oncological manner and if the principles of TME have been adhered to; for example, the macroscopic specimen evaluation, plane of surgery, quality of surgery and quality of the mesorectum. From this pathological assessment, the pathologist can 
gather prognostic information on local and overall recurrence, overall survival, and the need for adjuvant treatment, as well as helping in training and educating other MDT members ${ }^{35,110-112}$. Showing the TME specimen photographs during a rectal cancer MDT meeting, a National Accreditation Program for Rectal Cancer (NAPRC) standard, provides opportunities for education and quality improvement programs ${ }^{109}$ (FIG 8).

Pathological examination of TME specimens for rectal cancer consists of several steps, the first of which is assessment of the quality of the mesorectum. The integrity of the mesorectum is directly related to the plane of surgery at which the rectum and mesorectum has been resected; a surgical plane at the mesorectum has been shown critical to prevent local and distal recurrence ${ }^{35,113}$. Assessment of the plane of surgery has the following classification: Mesorectal plane (complete, intact mesorectum); intramesorectal (near complete, minor irregularities in the mesorectum with no exposure of the muscularis propria); and muscularis plane (incomplete, defects down to muscularis propria and/or very irregular circumferential margin) $)^{114,115}$.

The next step is determination of the pathological tumour stage before evaluation of the margins of resection. Several publications have demonstrated that the status of the circumferential (radial) margin of resection is one of the most important factors that influence local and distant recurrence ${ }^{116,117}$. A positive circumferential margin of resection is defined as the presence of tumour at or $<1 \mathrm{~mm}$ from the margin. Figure 9 demonstrates a pathological specimen with a positive CRM. Although a clear margin of resection should be obtained, the exact length of the distal margin is controversial and many studies have shown that distal margins of $1 \mathrm{~cm}$, or occasionally even less, 
achieve similar oncological results as longer margins ${ }^{118}$. The next step in examining a TME specimen is quantification of tumour response to neoadjuvant CRT. Several grading systems have been proposed to document the different degrees of tumour response. The College of American Pathologists recommends the following system: No residual tumour identified, grade 0; Moderate response, minimal residual disease, grade 1; minimal response, grade 2; and no definitive response, grade $3{ }^{114}$. International recommendations and the Royal College of Pathologists use a similar grading system: with no viable cancer cells (complete response), grade 0; single cells or rare small groups of cancer cells (near-complete response), grade 1; residual cancer with evident tumour regression, but more than single cells or rare small groups of cancer cells (partial response), grade 2; and extensive residual cancer with no evident tumour regression (poor or no response), grade $3^{115}$.

The final step is lymph node yield. The number of lymph nodes dissected from colorectal cancer specimens has long been recognised to affect prognosis, but it is important to emphasise that many patients with rectal cancer receive preoperative radiotherapy that has been shown to decrease the yield of lymph nodes from the surgical specimens ${ }^{119,120}$. The clinical significance of this occurrence is unclear and although some studies have shown no adverse effect on survival related to a low number of dissected numbers ${ }^{121}$, this subject remains controversial. Furthermore, a few studies have suggested that a decreased number of harvested nodes following radiotherapy might actually portend an adverse outcome ${ }^{122}$.

The resulting pathology report should always include a minimum of precise information of tumour and node stage and histological features that can affect 
prognosis, such as vascular invasion, EMVI, tumour growth pattern, response to preoperative chemoradiation and resection margin status, particularly the CRM.

\section{[H1] Role of the multidisciplinary team}

MDT meetings, also known as tumour boards, multidisciplinary cancer conferences, multidisciplinary case reviews or multidisciplinary clinics, provide a forum for multidisciplinary cancer teams to regularly convene and discuss the diagnostic and treatment aspects of patient care. Tumour boards were initially created in the USA in the 1970s; however, their primary goal was educational rather than improving patient care $^{123}$. The MDT concept was popularised and shifted focus towards delivery of care in the UK following the 1995 Calman-Hine report, which highlighted wide variations in all cancer outcomes and comparatively lower survival rates for colorectal cancer in the UK compared with other European countries ${ }^{124,125}$. Implementation of national treatment guidelines and quality standards ensued across the UK, many other European countries and Australia to improve cancer care, with mandatory MDT presentation, effective use of imaging, evidence-based medical and radiotherapy oncology and surgery, and pathological assessment of surgical quality, all as part of formalised cancer care ${ }^{126-129}$. The UK National Institute for Clinical Excellence guidelines on organising multidisciplinary care have since facilitated MDT implementation for rectal cancer management internationally ${ }^{130}$. Spain, Denmark, Norway and Sweden have successfully executed nationwide programmes with an MDT. The American College of Surgeons Committee on Cancer (CoC), in conjunction with the American Society of Colon and Rectal Surgeons, the Society for Surgery of the Alimentary Tract, the Society of American Gastrointestinal and Endoscopic Surgeons, the American College of Radiology, and the College of 
American Pathologists, have launched a national programme in the USA, the NAPRC, as the tool to improve rectal cancer quality with MDTs a central component in the programme $\mathrm{e}^{109,131}$.

The NAPRC is the newest initiative of the American College of Surgeons quality programmes, which work to improve quality outcomes by permitting comparisons amongst sites, sharing best practices and ensuring that the appropriate processes, procedures and personnel are in place to enable standards to be met or exceeded. The NAPRC includes a variety of standards, which will help ensure optimal patient outcomes $^{109}$. Leading these standards is the requirement for individual centres to be accredited by the CoC. Accreditation ensures that much of the infrastructure for the NAPRC and meeting baseline standards for reporting and quality are in place. It is anticipated that implementation of these measures will improve the quality of rectal cancer care throughout North America, and the rectal cancer MDT will become ubiquitous.

The rectal cancer MDT consists of surgeons, radiologists, pathologists, medical and radiation oncologists, and clinical nurse specialists, with other consultants and support staff involved as needed. The MDT reviews information and accumulates expert opinions so management decisions can be made on patient treatment and response, and enables individualisation for tailored, patient-specific treatment recommendations. It also captures the patient data and treatment recommendations in an institutional-level database, so internal audits can be performed to monitor outcomes, compliance with guidelines and institutional quality improvement ${ }^{132}$. The pillars of an MDT include: providing recommendations based on the team consensus 
and integrating the complementary areas of expertise; identifying gaps in current service provision and realigning care delivery with national guidelines; educating team members of developments within specific area of expertise; ensuring effective communication for coordination of care; data collection and audit of results; service redesign and improvement based on the results; continuous quality improvement in scheduling, staging, treatment, and surveillance; and encouraging participation in clinical trials ${ }^{133,134}$. To this end, every patient with a new diagnosis of rectal cancer is presented at least twice: once prior to definitive treatment and a second time after definitive treatment. During the first presentation, the rectal cancer protocol highresolution MRI is shown and discussed along with the CT scan of the chest, abdomen and pelvis and any other preoperative assessments. During the second conference, the TME photographs and other data derived from surgery for further treatment are shown and discussed.

There is still controversy on the benefit of the MDT. Several studies to date have supported improvement in coordination of care, preoperative clinical staging, multimodality treatment, pathological staging, and technical aspects of surgery after implementation of rectal cancer MDTs ${ }^{135}$. Patients presented at the MDT had substantially more accurate staging, with MRI used more often and TNM staging more complete ${ }^{136}$. MDT evaluation is an independent predictor for appropriate preoperative radiotherapy, even when controlling for co-morbidity and age ${ }^{137}$. With the MDT structure in place, an analysis of 49 cancer registries in 18 European countries found that rectal cancer-specific outcomes now match or even exceed the outcomes of colon cancer ${ }^{138}$. However, despite the widespread acceptance of a collaborative and organised approach to managing rectal cancer, little direct evidence 
exists that such meetings significantly improve outcomes. Wille-Jorgensen and colleagues examined the outcomes of almost 800 patients before and after the introduction of a formal MDT at two hospitals in Denmark ${ }^{139}$. Although they found increased information on staging, the use of pre-operative MRI and improved lymph node yield, local recurrence and overall survival rates showed no significant difference. A similar study from Scotland showed slightly different results on implantation of an MDT for colorectal cancer, in which there was improvement in cause-specific survival for all patients $(63.1 \%$ with an MDT versus $48.2 \%$ without an MDT; $P<0.0001)$, but subgroup analysis found the benefit from the MDT process was largely confined to patients with advanced disease (adjusted HR (early): 1.32, 95\% CI: $0.69-2.49, P=0.401$; adjusted HR(advanced): $0.65,95 \%$ CI: $0.45-0.96, P=0.031)$ 140. From this study, the authors questioned the belief that all new patients with colorectal cancer should be discussed at an MDT meeting. Perhaps the real question is not if the MDT process improved clinical outcomes, but if the appropriate outcomes were measured. At inception of MDTs, there were no baseline values gathered of the treatment offered, patient and tumour responses to treatment, or compliance, and no agreed method to measure implementation or effectiveness, so no reliable figures exist to gauge improvement ${ }^{141}$. A summary of the MDT data to date is found in Table 4.

Disadvantages of the MDT in general are also noted. First, there is a lack of patient involvement in the discussions, as patients are not present at these meetings, and it must be assured that patient preferences and their social circumstances are taken into account for the most appropriate team decisions. Divergent treatment priorities with a failure to reach a joint recommendation have been commonly reported, as well as 
poor leadership, insufficient teamwork, time pressures, an absence of key professionals in attendance and the absence of key clinical information; all of which can affect the clinical decision making of MDTs in general ${ }^{142,143}$. MDTs remain a work in progress but continue to add benefit for management during their evolution.

\section{[H1] Conclusions}

Rectal cancer is a global health issue, with an increasing incidence in younger patient populations. Treatment options have expanded during the past 40 years, leading to better outcomes and improved quality of life. The management of rectal cancer continues to progress, with advances in staging to better determine patient prognosis, the increasing use of surgical technology to offer more precise surgery, more personalised treatment based on meticulous pathology and the standardisation of surgical techniques for curative resections. Unfortunately, treatment outcomes, including the rates of permanent colostomy, CRM positivity, lymph node yield, local recurrence, survival and adherence to evidence-based guidelines is widely variable and highly surgeon and centre specific. It is clear that rectal cancer is a highly complex disease in which optimal outcomes are seen in centres that treat the highest volume of patients in an MDT approach, strengthening calls for centralisation of expertise.

During the past 40 years, rectal cancer management has grown from a surgerydominated strategy to one that includes evidence-based, multimodal screening, diagnosis, treatment and surveillance, coordinated across all periods of care by the MDT. The modern multidisciplinary team for rectal cancer is an active process in which interlinked disciplines consider all patient, tumour diagnostic and staging 
information to formulate the best treatment strategy for the patient. These collaborative recommendations from experts across all disciplines caring for the patient have improved surgical quality, recurrence, survival and adherence to consensus guidelines ${ }^{144,145}$.

As novel imaging and therapeutic regimens evolve, there are great implications of the MDT for risk stratification and defining precision treatment plans, which in some cases might even obviate the need for surgery. Furthermore, as multidisciplinary management is introduced as the standard of care in the USA, and continues to evolve in Europe and the UK, there is an opportunity to review the role of the MDT and its constituent elements to ensure that we work to continually improve quality and outcomes in rectal cancer. 
Figure 1 | Worldwide colorectal cancer incidence and mortality rates. Agestandardized rates (ASR) of incidence (a) and mortality (b) are shown for colorectal cancer for both sexes. Data from GLOBOCAN 2018 (ref.4).

Figure 2 | MRI-directed treatment decision making for rectal cancer. Example of options to guide discussion based on MRI for a rectal cancer presentation to the multidisciplinary tumour board. [Au: Please carefully check all the text on this figure.]

THIS IS FINE

Figure 3 | The mesorectal fascia and oncological planes. a | Coronal T2-weighted MRI showing mesorectal fat with a high signal intensity. The mesorectal fat is surrounded by the mesorectal fascia (MRF), shown by a fine line of low signal intensity (black arrows). b | Coronal T2-weighted MRI demonstrating tumour distance from the MRF and threatening of the MRF. The MRF is the resection plane for a total mesorectal excision (TME) and has to be tumor-free for an R0 resection. A distance of the tumor to the MRF of $<1 \mathrm{~mm}$ is called an involved MRF and not suitable for TME. Here, there is posterior MRF involvement (short white arrow) and a positive lymph node (long white arrow) in the mesorectal fat.

Figure 4 | MRI demonstrating extramural venous invasion by a rectal tumour. MRI showing extramural venous invasion before (a) and after neoadjuvant chemoradiotherapy (b). The arrows point to the venous invasion. 
Figure 5 | Multidisciplinary team treatment algorithm for rectal cancer. An example is shown of the discussion flow for a rectal cancer presentation to the multidisciplinary tumour (MDT) board. CRM, circumferential resection margin; Mx, ; Nx, [Au: Please carefully check all the text on this figure. Do Mx and Nx require a definition in the legend?]

-THERE IS A TYPO IN THE FIGURE CREATED, ${ }^{\mathrm{TH}}$ LINE T3-T4NNXMXSHOULD READ T4NXMX (THERE WAS AN ADDITIONAL N INSERTED)

-X- not possible to determine

Figure 6 | Total mesorectal excision plane. This schematic shows the pelvic and total mesorectal excision plane, where the rectum and mesorectal fat are excised en bloc. The dotted line marks the line of excision.

Figure 7 | Surgical approaches for rectal cancer. The anterior dissection for a total mesorectal excision is demonstrated using different surgical approaches: open (a); laparoscopic (b); robotic (c); and transanal (d). Photos courtesy of D.S.K.

Figure 8 | Complete total mesorectal excision specimen. Examination of a complete total mesorectal excision specimen is performed in three planes (posterior view (a), anterior view (b) and coronal view (c)), noting the intact mesorectum with only minor irregularities of the smooth surface, no defects $>5 \mathrm{~mm}$ on the mesorectum, no coning towards the distal margin of the specimen, and a smooth circumferential resection margin on slicing. 
Figure 9 | Positive pathological circumferential resection margin. Positive pathological margin, demonstrated with haematoxylin and eosin stain at 400x magnification. Malignant cells are present at the circumferential margin of resection (noted with arrow). [Au: Can you account for the green colour in this image, was there another stain used as well as H\&E here? Can you please account for who owns this image. If it is owned by someone not in the author list we will have to obtain permission for its use.]

THE STAINS ARE AS ALREADY NOTED BY DR BERHO. THERE IS NO FURTHER INFORMATION NEEDED. THIS IS HER IMAGE, IT HAS NOT BEEN USED OR PUBLISHED OR OWNED BY ANYONE ELSE 
Table 1-Key trials in radiotherapy and chemotherapy for rectal cancer

\begin{tabular}{|c|c|c|c|c|c|}
\hline Trial & Date & $\begin{array}{l}\text { Tumour } \\
\text { stage }\end{array}$ & Comparison & Results & Conclusion \\
\hline $\begin{array}{l}\text { Swedish rectal } \\
\text { cancer trial }^{146}\end{array}$ & 1997 & II and III & $\begin{array}{l}\text { Surgery alone } \\
\text { vs. preoperative } \\
\text { short course } \\
\text { XRT }\end{array}$ & $\begin{array}{l}5 \text {-year local } \\
\text { recurrence } 27 \% \\
\text { vs. } 11 \% \\
(P<0.001) \text {; } 5 \text { - } \\
\text { year survival rate } \\
\text { was } 48 \% \text { vs. } 58 \% \\
(P=0.004)\end{array}$ & $\begin{array}{l}\text { Preoperative XRT } \\
\text { reduced local } \\
\text { recurrence and } \\
\text { improved survival }\end{array}$ \\
\hline Dutch TME trial $^{147}$ & 2001 & II and III & $\begin{array}{l}\text { TME alone vs. } \\
\text { preoperative } \\
\text { short course } \\
\text { XRT and TME }\end{array}$ & $\begin{array}{l}\text { 2-year local } \\
\text { recurrence was } \\
8.2 \% \text { vs. } 2.4 \% \\
(P<0.001)\end{array}$ & $\begin{array}{l}\text { Preoperative XRT } \\
\text { reduces local } \\
\text { recurrence with a } \\
\text { standardised TME }\end{array}$ \\
\hline $\begin{array}{l}\text { German trial } \\
\text { CAO/ARO/AIO-9148 }\end{array}$ & 2004 & II and III & $\begin{array}{l}\text { Preoperative vs. } \\
\text { postoperative } \\
\text { chemoXRT }\end{array}$ & $\begin{array}{l}5 \text {-year local } \\
\text { recurrence was } \\
6 \% \text { vs.13\% } \\
(P=0.006) \text { and } 5- \\
\text { year survival } \\
\text { were } 76 \% \text { vs. } \\
74 \%(P=0.80)\end{array}$ & $\begin{array}{l}\text { Preoperative } \\
\text { chemoXRT, } \\
\text { improved local } \\
\text { control but not } \\
\text { overall survival }\end{array}$ \\
\hline EORTC $22921^{149}$ & 2006 & II and III & $\begin{array}{l}\text { Preoperative } \\
\text { XRT, } \\
\text { preoperative } \\
\text { chemoXRT, } \\
\text { preoperative } \\
\text { XRT and } \\
\text { postoperative } \\
\text { XRT, or } \\
\text { preoperative } \\
\text { chemoXRT and } \\
\text { postoperative } \\
\text { chemotherapy }\end{array}$ & $\begin{array}{l}\text { No difference in } \\
\text { overall survival } \\
\text { between pre and } \\
\text { postoperative } \\
\text { chemotherapy. 5- } \\
\text { year local } \\
\text { recurrence } 8.7 \% \text {, } \\
9.6 \%, 7.6 \% \text {, and } \\
17.1 \% \text { with } \\
\text { chemotherapy } \\
\text { preoperatively, } \\
\text { postoperatively, } \\
\text { both, or none } \\
(P=0.002)\end{array}$ & $\begin{array}{l}\text { With preoperative } \\
\text { XRT, adding } \\
\text { chemotherapy pre or } \\
\text { postoperatively had } \\
\text { no significant effect } \\
\text { on survival. } \\
\text { Chemotherapy, } \\
\text { before or after } \\
\text { surgery, added } \\
\text { significant benefit to } \\
\text { local control. }\end{array}$ \\
\hline $\operatorname{ADORE}^{150}$ & 2014 & II and III & $\begin{array}{l}\text { Adjuvant } \\
\text { FOLFOX vs. 5- } \\
\text { FU/ leucovorin } \\
\text { after } \\
\text { preoperative } \\
\text { chemoXRT }\end{array}$ & $\begin{array}{l}\text { 3-year disease } \\
\text { free survival } 72 \% \\
\text { vs. } 62 \% \\
(P=0.047)\end{array}$ & $\begin{array}{l}\text { FOLFOX improves } \\
\text { disease-free survival } \\
\text { compared to 5-FU/ } \\
\text { leucovorin after } \\
\text { preoperative } \\
\text { chemoXRT and } \\
\text { TME }\end{array}$ \\
\hline $\begin{array}{l}\text { German Trial } \\
\text { CAO/ARO/AIO-04 } \\
151\end{array}$ & 2015 & II and III & $\begin{array}{l}\text { Neoadjuvant } \\
\text { and adjuvant } \\
\text { FOLFOX vs. 5- } \\
\text { FU/ leucovorin }\end{array}$ & $\begin{array}{l}3 \text {-year disease- } \\
\text { free survival } 76 \% \\
\text { vs. } 71 \%(P=0.03)\end{array}$ & $\begin{array}{l}\text { Adding oxaliplatin } \\
\text { improves survival } \\
\text { response }\end{array}$ \\
\hline
\end{tabular}


5-FU, fluorouracil; FOLFOX, folinic acid, 5-FU and oxaliplatin; chemoXRT, chemoradiotherapy; TME, total mesorectal excision; XRT, radiotherapy. 
Table 2- Controlled trials for laparoscopic and open resection in rectal cancer

\begin{tabular}{|c|c|c|c|c|c|c|c|c|c|c|}
\hline \multirow[t]{2}{*}{ Study } & \multicolumn{2}{|c|}{$\begin{array}{l}\text { Number of } \\
\text { patients }\end{array}$} & \multicolumn{2}{|c|}{$\mathrm{CRM}(<1 \mathrm{~mm})$} & \multicolumn{2}{|c|}{ TME integrity } & \multicolumn{2}{|c|}{ Lymph nodes } & \multicolumn{2}{|c|}{$\begin{array}{l}\text { Local Recurrence } \\
\text { ( } 3 \text { or } 5 \text { years) }\end{array}$} \\
\hline & Lap & Open & Lap & Open & Lap & Open & Lap & Open & Lap & Open \\
\hline $\begin{array}{l}\text { Guillou }^{152} \\
2005 \\
\text { CLASICC }\end{array}$ & 253 & 128 & $88.2 \%$ & $90.1 \%$ & NA & $\mathrm{NA}$ & 12 & 13.5 & $10.8 \%$ & $8.7 \%$ \\
\hline $\begin{array}{l}\text { Laurent }^{153} \\
2009\end{array}$ & 238 & 233 & $93.3 \%$ & $95.3 \%$ & NA & NA & NA & NA & $3.8 \%$ & $5.1 \%$ \\
\hline $\begin{array}{l}\text { Lujan }^{154} \\
2013\end{array}$ & 1387 & 3018 & $90.5 \%$ & $83.7 \%$ & NA & NA & 14.5 & 14.7 & $3.9 \%$ & $4.8 \%$ \\
\hline $\begin{array}{l}\text { Van der } \\
\text { Pas }^{58} \\
2013 \\
\text { Color II }\end{array}$ & 588 & 300 & $90.5 \%$ & $90 \%$ & $88.5 \%$ & $91.5 \%$ & 13.0 & 14.0 & $5 \%$ & $5 \%$ \\
\hline $\begin{array}{l}\text { Kang }^{62} \\
2010 \\
\text { COREAN }\end{array}$ & 170 & 170 & $97.1 \%$ & $95.9 \%$ & $73.4 \%$ & $74.8 \%$ & 17.0 & 18.0 & $2.6 \%$ & $4.9 \%$ \\
\hline $\begin{array}{l}\text { Fleshman }^{67} \\
2018 \\
\text { ACOSOG } \\
\text { Z6051 }\end{array}$ & 240 & 222 & $88 \%$ & $92 \%$ & $88 \%$ & $92 \%$ & NA & NA & $4.6 \%$ & $4.5 \%$ \\
\hline $\begin{array}{l}\text { Stevenson }^{68} \\
2018 \\
\text { ALACART }\end{array}$ & 225 & 225 & $93 \%$ & $97 \%$ & $87 \%$ & $92 \%$ & NA & $\mathrm{NA}$ & $5.4 \%$ & $3.1 \%$ \\
\hline
\end{tabular}

CRM, circumferential resection margin; NA, not available; TME, total mesorectal excision. 
Table 3- Controlled trials for laparoscopic and open resection in rectal cancer- Conversion Rate as an Endpoint

\begin{tabular}{|c|c|c|c|c|c|c|c|c|c|c|c|}
\hline \multirow[t]{2}{*}{ Author } & \multicolumn{2}{|c|}{$\begin{array}{l}\text { Number of } \\
\text { patients }\end{array}$} & \multicolumn{2}{|c|}{$\begin{array}{c}\text { Negative } \\
\text { CRM }\end{array}$} & \multicolumn{2}{|c|}{$\begin{array}{c}\text { TME } \\
\text { Complete }\end{array}$} & \multicolumn{2}{|c|}{$\begin{array}{c}\text { Distal Margin } \\
\text { Clear }\end{array}$} & \multicolumn{2}{|c|}{$\begin{array}{l}\text { Successful } \\
\text { Resection }\end{array}$} & \multirow[t]{2}{*}{ Converted } \\
\hline & Lap & Open & Lap & Open & Lap & Open & Lap & Open & Lap & Open & \\
\hline $\begin{array}{l}\text { Fleshman } \\
652015 \\
\text { ACOSOG } \\
\text { Z6051 } \\
\text { (Stage II } \\
\text { and III) }\end{array}$ & 240 & 222 & $88 \%$ & $92 \%$ & $88 \%$ & $92 \%$ & $>98 \%$ & $>98 \%$ & $82 \%$ & $87 \%$ & $11.3 \%$ \\
\hline $\begin{array}{l}\text { Stevenson } \\
2015^{64} \\
\text { ALaCaRT } \\
\text { (Stages I, } \\
\text { II, \& III) }\end{array}$ & 238 & 235 & $93 \%$ & $97 \%$ & $87 \%$ & $92 \%$ & $99 \%$ & $99 \%$ & $82 \%$ & $89 \%$ & $9 \%$ \\
\hline
\end{tabular}

CRM, circumferential resection margin; TME, total mesorectal excision. 
Table 4 | Summary of multidisciplinary tumour board effect on outcomes in colorectal cancer [Au: Please can you add a numbered reference citation to each study in this table. Can you also incorporate the additional references to the end of your reference list using your reference manager. I left another note about this at the end of your references ]

\begin{tabular}{|c|c|c|c|c|c|c|c|}
\hline Study & Country & Period & Patients & Comparison & $\begin{array}{c}\text { Key } \\
\text { differences }\end{array}$ & $\begin{array}{l}\text { Survival } \\
\text { outcome }\end{array}$ & $\begin{array}{l}\text { Risk of } \\
\text { recurrence } \\
\text { or death }\end{array}$ \\
\hline $\begin{array}{l}\text { Segelman } \\
\text { et al. } \\
2009^{155}\end{array}$ & Sweden & $\begin{array}{l}1995- \\
2004\end{array}$ & $\begin{array}{l}\text { Patients with } \\
\text { stage IV CRC } \\
\text { (689 with } \\
\text { colon cancer } \\
\text { and } 352 \text { with } \\
\text { rectal cancer) }\end{array}$ & $\begin{array}{c}\text { Patients } \\
\text { selected for } \\
\text { metastatic } \\
\text { surgery (39 } \\
\text { patients with } \\
\text { colon cancer } \\
\text { and } 38 \text { patients } \\
\text { with rectal } \\
\text { cancer) }\end{array}$ & $\begin{array}{l}\text { Patients } \\
\text { with rectal } \\
\text { cancer } \\
\text { more likely } \\
\text { that colon } \\
\text { cancer to } \\
\text { have } \\
\text { surgery for } \\
\text { metastases } \\
(8.5 \% \text { vs. } \\
3.9 \%)\end{array}$ & $\begin{array}{c}37 \% \text { 5-year } \\
\text { survival with } \\
\text { metastasis } \\
\text { surgery vs. } \\
2 \% \text { without } \\
\text { metastasis } \\
\text { surgery }\end{array}$ & NA \\
\hline $\begin{array}{l}\text { Lordan et } \\
\text { al. } 2009^{156}\end{array}$ & UK & $\begin{array}{c}1996- \\
2006\end{array}$ & $\begin{array}{l}331 \text { metastatic } \\
\text { CRC cases to } \\
\text { the liver }\end{array}$ & $\begin{array}{l}108 \text { patients } \\
\text { referred to an } \\
\text { MDT that } \\
\text { included a } \\
\text { liver surgeon } \\
\text { vs. } 223 \\
\text { patients } \\
\text { directly } \\
\text { referred to a } \\
\text { specialist } \\
\text { hepatobiliary } \\
\text { unit }\end{array}$ & NA & $\begin{array}{c}\text { Referral via } \\
\text { an MDT } \\
\text { involving a } \\
\text { liver surgeon } \\
\text { had 1-year, } \\
\text { 3-year and } \\
5 \text {-year } \\
\text { survival of } \\
89.6 \% \text {, } \\
67.5 \% \text { and } \\
49.9 \% \text { vs. } \\
90.3 \% \text {, } \\
54.1 \% \text { and } \\
43.3 \% \text {, } \\
\text { respectively, } \\
\text { among those } \\
\text { referred to } \\
\text { local MDTs }\end{array}$ & $\begin{array}{c}\text { Overall } \\
\text { mortality } \\
\text { was } \\
\text { improved } \\
\text { with referral } \\
\text { via an MDT } \\
\text { process }\end{array}$ \\
\hline
\end{tabular}




\begin{tabular}{|c|c|c|c|c|c|c|c|}
\hline $\begin{array}{c}\text { MacDermid } \\
\text { et al. } \\
2009^{157}\end{array}$ & UK & $\begin{array}{l}1997- \\
2005\end{array}$ & $\begin{array}{l}310 \text { patients } \\
\text { undergoing } \\
\text { colectomy for } \\
\text { CRC by a } \\
\text { single surgeon }\end{array}$ & $\begin{array}{l}176 \text { patients } \\
\text { pre-MDT } \\
\text { introduction } \\
\text { (1997- 2002) } \\
\text { vs. } 134 \\
\text { patients post- } \\
\text { MDT } \\
\text { introduction } \\
\text { (2002-2005) }\end{array}$ & $\begin{array}{l}\text { More } \\
\text { patients } \\
\text { prescribed } \\
\text { adjuvant } \\
\text { chemothera } \\
\text { py after } \\
\text { MDT } \\
\text { introduced }\end{array}$ & $\begin{array}{c}\text { 3-year } \\
\text { survival was } \\
58 \% \text { pre- } \\
\text { MDT and } \\
66 \% \text { in post- } \\
\text { MDT }\end{array}$ & $\begin{array}{l}\text { MDT status } \\
\text { was an } \\
\text { independent } \\
\text { predictor of } \\
\text { survival }\end{array}$ \\
\hline $\begin{array}{l}\text { Palmer et } \\
\text { al. } 2011^{158}\end{array}$ & Sweden & $\begin{array}{l}1995- \\
2004\end{array}$ & $\begin{array}{l}303 \text { patients } \\
\text { with locally } \\
\text { advanced } \\
\text { primary rectal } \\
\text { cancer from a } \\
\text { population- } \\
\text { based registry }\end{array}$ & $\begin{array}{l}\text { Preoperative } \\
\text { radiological } \\
\text { tumour staging } \\
\text { with } \\
\text { discussion at } \\
\text { an MDT } \\
\text { (group 1) vs. } \\
\text { preoperative } \\
\text { staging with } \\
\text { no MDT } \\
\text { discussion } \\
\text { (group 2) vs. } \\
\text { no } \\
\text { preoperative } \\
\text { radiological } \\
\text { staging (group } \\
\text { 3) }\end{array}$ & $\begin{array}{l}\text { R0 } \\
\text { resection } \\
\text { rate } \\
\text { differed } \\
\text { between } \\
\text { groups } \\
(52 \% \text { in } \\
\text { group 1, } \\
43 \% \text { in } \\
\text { group } 2 \text { and } \\
21 \% \text { in } \\
\text { group 3) }\end{array}$ & $\begin{array}{c}\text { Local } \\
\text { tumour } \\
\text { control was } \\
\text { achieved in } \\
57 \%, 36 \%, \\
\text { and } 19 \% \text { of } \\
\text { patients in } \\
\text { groups } 1,2 \\
\text { and } 3, \\
\text { respectively }\end{array}$ & $\begin{array}{c}\text { The } \\
\text { estimated } \\
\text { overall } \\
5 \text {-year } \\
\text { survival of } \\
\text { patients was } \\
30 \%, 28 \% \\
\text { and 12\% in } \\
\text { groups 1, } \\
\text { and 3, } \\
\text { respectively. }\end{array}$ \\
\hline $\begin{array}{l}\text { Du et al. } \\
2011^{159}\end{array}$ & China & $\begin{array}{l}2001- \\
2005\end{array}$ & $\begin{array}{l}263 \text { resectable } \\
\text { locally } \\
\text { advanced } \\
\text { rectal cancer } \\
\text { cases }\end{array}$ & $\begin{array}{c}\text { Neoadjuvant } \\
\text { therapy with } \\
\text { MDT } \\
\text { treatment } \\
\text { versus control } \\
\text { with direct } \\
\text { surgery and } \\
\text { postoperative } \\
\text { adjuvant } \\
\text { therapy }\end{array}$ & $\begin{array}{l}\text { The MDT } \\
\text { altered the } \\
\text { treatment } \\
\text { strategy in } \\
58.33 \%\end{array}$ & $\begin{array}{c}\text { 5-year } \\
\text { overall } \\
\text { survival rate } \\
\text { was higher } \\
\text { in the MDT } \\
\text { and } \\
\text { neoadjuvant } \\
\text { group than } \\
\text { in control } \\
\text { group } \\
(77.23 \% \text { vs } \\
69.75 \%)\end{array}$ & $\begin{array}{l}\text { Local tumor } \\
\text { control was } \\
\text { better with } \\
\text { neoadjuvant } \\
\text { therapy and } \\
\text { MDT }\end{array}$ \\
\hline
\end{tabular}




\begin{tabular}{|c|c|c|c|c|c|c|c|}
\hline $\begin{array}{l}\text { Ye et al. } \\
2012^{160}\end{array}$ & China & $\begin{array}{l}1999- \\
2006\end{array}$ & $\begin{array}{l}595 \text { patients } \\
\text { with CRC } \\
\text { from January } \\
1999 \text { to } \\
\text { September } \\
2006\end{array}$ & $\begin{array}{l}297 \text { patients } \\
\text { pre-MDT } \\
\text { cohort 1999- } \\
2002 \text { and } 298 \\
\text { patients post- } \\
\text { MDT 2002- } \\
2006\end{array}$ & $\begin{array}{l}\text { Number of } \\
\text { examined } \\
\text { lymph } \\
\text { nodes and } \\
\text { accuracy of } \\
\text { TNM } \\
\text { staging by } \\
\text { CT }\end{array}$ & $\begin{array}{l}\text { Age, } \\
\text { treatment } \\
\text { after MDT } \\
\text { inception, } \\
\text { degree of } \\
\text { differentiatio } \\
\text { n, number of } \\
\text { lymph nodes } \\
\text { examined, } \\
\text { and TNM } \\
\text { stage }\end{array}$ & $\begin{array}{l}\text { Lower rate } \\
\text { of tumour } \\
\text { recurrence } \\
\text { post-MDT }\end{array}$ \\
\hline $\begin{array}{l}\text { Levine et } \\
\text { al. } 2012^{161}\end{array}$ & USA & $\begin{array}{c}2008- \\
2009\end{array}$ & $\begin{array}{l}\text { Prospective } \\
\text { study of } \\
\text { patients with } \\
\text { CRC }\end{array}$ & $\begin{array}{l}\text { Patients } \\
\text { referred to the } \\
\text { MDT vs. } \\
\text { patients } \\
\text { managed } \\
\text { outside }\end{array}$ & $\begin{array}{l}62.5 \% \text { of } \\
\text { MDT } \\
\text { patients vs. } \\
41.5 \% \text { of } \\
\text { control } \\
\text { patients had } \\
\text { peri- } \\
\text { operative } \\
\text { treatment } \\
(P=0.02)\end{array}$ & NA & $\begin{array}{c}76 \% \text { of } \\
\text { MDT } \\
\text { patients with } \\
\text { rectal cancer } \\
\text { vs. } 20 \% \text { of } \\
\text { control } \\
\text { patients } \\
\text { underwent } \\
\text { neoadjuvant } \\
\text { therapy }\end{array}$ \\
\hline $\begin{array}{l}\text { Wille- } \\
\text { Jorgensen } \\
\text { et al. } \\
2013^{139}\end{array}$ & $\begin{array}{c}\text { Denmar } \\
\mathrm{k}\end{array}$ & $\begin{array}{c}2001- \\
2006\end{array}$ & $\begin{array}{c}811 \text { patients } \\
\text { with rectal } \\
\text { cancer treated } \\
\text { at two } \\
\text { hospitals }\end{array}$ & $\begin{array}{c}\text { Outcomes } 3 \\
\text { years before } \\
\text { MDT } \\
\text { introduction } \\
\text { vs. the first } 2 \\
\text { years after } \\
\text { MDT }\end{array}$ & $\begin{array}{l}\text { The } \\
\text { frequency } \\
\text { of } \\
\text { preoperativ } \\
\text { e MRI } \\
\text { scans } \\
\text { increased in } \\
\text { the MDT } \\
\text { cohort }\end{array}$ & $\begin{array}{c}\text { No } \\
\text { difference in } \\
\text { overall } \\
\text { survival }\end{array}$ & $\begin{array}{c}\text { More } \\
\text { metachronou } \\
\text { s distant } \\
\text { metastases } \\
\text { were found } \\
\text { in the MDT } \\
\text { cohort }\end{array}$ \\
\hline $\begin{array}{l}\text { Prades et } \\
\text { al. } 2015^{162}\end{array}$ & $\begin{array}{l}\text { Systemat } \\
\text { ic } \\
\text { review }\end{array}$ & $\begin{array}{c}2005- \\
2012\end{array}$ & $\begin{array}{l}51 \text { papers that } \\
\text { evaluated } \\
\text { MDT clinical } \\
\text { practice and } \\
\text { organisation } \\
\text { in cancer care }\end{array}$ & NA & $\begin{array}{l}\text { MDT was } \\
\text { associated } \\
\text { with } \\
\text { changes in } \\
\text { clinical } \\
\text { diagnostic } \\
\text { and } \\
\text { treatment } \\
\text { decision- } \\
\text { making }\end{array}$ & NA & $\begin{array}{l}\text { Evidence of } \\
\text { improved } \\
\text { survival was } \\
\text { found for } \\
\text { CRC based } \\
\text { on four } \\
\text { studies }\end{array}$ \\
\hline
\end{tabular}




\begin{tabular}{|c|c|c|c|c|c|c|c|}
\hline $\begin{array}{l}\text { Brännström } \\
2015^{137}\end{array}$ & Sweden & $\begin{array}{c}2007- \\
2010\end{array}$ & $\begin{array}{l}5,273 \text { patients } \\
\text { that had MDT } \\
\text { care from the } \\
\text { Swedish } \\
\text { Rectal Cancer } \\
\text { Register }\end{array}$ & NA & $\begin{array}{l}\text { Hospital } \\
\text { volume, } \\
\text { patient age } \\
\text { and tumour } \\
\text { stage } \\
\text { influenced } \\
\text { the chance } \\
\text { of MDT } \\
\text { evaluation }\end{array}$ & $\begin{array}{c}\text { MDT } \\
\text { evaluation } \\
\text { predicted the } \\
\text { likelihood of } \\
\text { being treated } \\
\text { with } \\
\text { preoperative } \\
\text { radiotherapy } \\
\text { in an } \\
\text { appropriate } \\
\text { patient }\end{array}$ & NA \\
\hline $\begin{array}{l}\text { Munro et } \\
\text { al. } 2015^{140}\end{array}$ & Scotland & $\begin{array}{l}2006- \\
2007\end{array}$ & $\begin{array}{l}\text { Population- } \\
\text { based cohort } \\
\text { of } 586 \\
\text { consecutive } \\
\text { patients with } \\
\text { CRC }\end{array}$ & $\begin{array}{l}411 \text { patients that } \\
\text { had MDT } \\
\text { presentation } \\
\text { and followed } \\
\text { recommendatio } \\
\text { n vs. } 175 \text { never } \\
\text { discussed/ } \\
\text { MDT } \\
\text { recommendatio } \\
\text { n not followed }\end{array}$ & $\begin{array}{l}\text { Any benefit } \\
\text { from the } \\
\text { MDT } \\
\text { confined to } \\
\text { patients } \\
\text { with } \\
\text { advanced } \\
\text { disease: } \\
\text { adjusted } \\
\text { HR: } 0.65 \\
(0.45-0.96)\end{array}$ & NA & $\begin{array}{l}\text { HR for death } \\
\text { from } \\
\text { colorectal } \\
\text { cancer was } \\
0.73(0.53- \\
1.00, \\
P=0.047) \text { in } \\
\text { the MDT } \\
\text { group }\end{array}$ \\
\hline $\begin{array}{l}\text { Richardson } \\
\text { et al. } \\
2016^{135}\end{array}$ & USA & $\begin{array}{c}2010- \\
2014\end{array}$ & $\begin{array}{l}130 \text { patients } \\
\text { with CRC }\end{array}$ & $\begin{array}{c}42 \text { patients } \\
\text { pre-MDT and } \\
88 \text { patients } \\
\text { with MDT and } \\
\text { TME }\end{array}$ & $\begin{array}{l}\text { Improveme } \\
\text { nt in the } \\
\text { completene } \\
\text { ss of TME } \\
\text { with an } \\
\text { MDT }(0 \% \\
\text { to } 76 \%\end{array}$ & NA & $\begin{array}{l}\text { Local } \\
\text { recurrence in } \\
10 \% \text { in pre- } \\
\text { MDT group }\end{array}$ \\
\hline
\end{tabular}

CRC, colorectal cancer; HR, hazard ratio; MDT, multidisciplinary team; NA, not available; TME, total mesorectal excision 
1. $\quad$ Siegel, R. L., Miller, K. D. \& Jemal, A. Cancer statistics, 2018. CA Cancer J Clin 68, 7-30 (2018).

2. Siegel, R. L., Miller, K. D. \& Jemal, A. Cancer Statistics, 2017. CA Cancer J Clin 67, 7-30 (2017).

3. Henley, S. J. et al. Invasive cancer incidence and survival--United States, 2011. MMWR Morb Mortal Wkly Rep 64, 237-242 (2015).

4. Ferlay J, Ervik M, Lam F, Colombet M, Mery L, Piñeros M, Znaor A, Soerjomataram I, Bray F (2018). Global Cancer Observatory: Cancer Today. Lyon, France: International Agency for Research on Cancer. Available from: https://gco.iarc.fr/today.

5. Vuik, F. E. et al. Increasing incidence of colorectal cancer in young adults in Europe over the last 25 years. Gut 68, 1820-1826 (2019).

6. Petrelli, F., Sgroi, G., Sarti, E. \& Barni, S. Increasing the Interval Between Neoadjuvant Chemoradiotherapy and Surgery in Rectal Cancer: A Metaanalysis of Published Studies. Ann Surg 263, 458-464 (2016).

7. Foster, J. D., Jones, E. L., Falk, S., Cooper, E. J. \& Francis, N. K. Timing of surgery after long-course neoadjuvant chemoradiotherapy for rectal cancer: a systematic review of the literature. Dis Colon Rectum 56, 921-930 (2013).

8. Sun, Z. et al. Optimal Timing to Surgery after Neoadjuvant Chemoradiotherapy for Locally Advanced Rectal Cancer. J Am Coll Surg 222, 367-374 (2016).

9. Lefevre, J. H. et al. Effect of Interval (7 or 11 weeks) Between Neoadjuvant Radiochemotherapy and Surgery on Complete Pathologic Response in Rectal Cancer: A Multicenter, Randomized, Controlled Trial (GRECCAR-6). J Clin Oncol 34, 3773-3780 (2016).

10. National Institute for Health and Care Excellence (NICE);. Colorectal cancer: diagnosis and management. Clinical guideline [CG131], (2014).

11. Benson, A. B. et al. Rectal Cancer, Version 2.2018, NCCN Clinical Practice Guidelines in Oncology. J Natl Compr Canc Netw 16, 874-901 (2018).

12. Wibe, A. et al. Prognostic significance of the circumferential resection margin following total mesorectal excision for rectal cancer. Br J Surg 89, 327-334 (2002).

13. Balyasnikova, S. \& Brown, G. Optimal Imaging Strategies for Rectal Cancer Staging and Ongoing Management. Curr Treat Options Oncol 17, 32 (2016).

14. Taylor, F. G. et al. One millimetre is the safe cut-off for magnetic resonance imaging prediction of surgical margin status in rectal cancer. Br J Surg 98, 872879 (2011).

15. Glynne-Jones, R. et al. Rectal cancer: ESMO Clinical Practice Guidelines for diagnosis, treatment and follow-up. Ann Oncol 28, iv22-iv40 (2017).

16. Merkel, S. et al. The prognostic inhomogeneity in pT3 rectal carcinomas. Int $J$ Colorectal Dis 16, 298-304 (2001).

17. Ramesh, H., Bedi, M. S. \& Sikora, S. S. Extent of mesorectal tumor invasion as a prognostic factor after curative surgery for T3 rectal cancer patients. Ann Surg 244, 835-6; author reply 836 (2006).

18. Willett, C. G., Badizadegan, K., Ancukiewicz, M. \& Shellito, P. C. Prognostic factors in stage T3N0 rectal cancer: do all patients require postoperative pelvic irradiation and chemotherapy. Dis Colon Rectum 42, 167-173 (1999).

19. Taylor, F. G. et al. Preoperative high-resolution magnetic resonance imaging can identify good prognosis stage I, II, and III rectal cancer best managed by 
surgery alone: a prospective, multicenter, European study. Ann Surg 253, 711719 (2011).

20. Georgiou, P. A. et al. Diagnostic accuracy and value of magnetic resonance imaging (MRI) in planning exenterative pelvic surgery for advanced colorectal cancer. Eur J Cancer 49, 72-81 (2013).

21. Tekkis PP, G. P. A., Constantinides VA, Patel U, Antoniou A, Goldin RD, Darzi AW, Cunningham D, Nicholls R, Brown G. Diagnostic accuracy and value of magnetic resonance imaging (MRI) in planning exenterative pelvic surgery for advanced colorectal pelvic cancer. Journal of Clinical Oncology 2011 29:4_suppl, 370-370

22. Chadi, S. A. et al. Factors affecting local regrowth after watch and wait for patients with a clinical complete response following chemoradiotherapy in rectal cancer (InterCoRe consortium): an individual participant data meta-analysis. Lancet Gastroenterol Hepatol 3, 825-836 (2018).

23. Habr-Gama, A. et al. Baseline T Classification Predicts Early Tumor Regrowth After Nonoperative Management in Distal Rectal Cancer After Extended Neoadjuvant Chemoradiation and Initial Complete Clinical Response. Dis Colon Rectum 60, 586-594 (2017).

24. Chand, M., Siddiqui, M. R., Swift, I. \& Brown, G. Systematic review of prognostic importance of extramural venous invasion in rectal cancer. World $J$ Gastroenterol 22, 1721-1726 (2016).

25. Talbot, I. C. et al. The clinical significance of invasion of veins by rectal cancer. Br J Surg 67, 439-442 (1980).

26. Smith, N. J. et al. Prognostic significance of magnetic resonance imagingdetected extramural vascular invasion in rectal cancer. Br J Surg 95, 229-236 (2008).

27. Smith, N. J., Shihab, O., Arnaout, A., Swift, R. I. \& Brown, G. MRI for detection of extramural vascular invasion in rectal cancer. AJR Am J Roentgenol 191, 1517-1522 (2008).

28. Battersby, N. J. et al. Prospective Validation of a Low Rectal Cancer Magnetic Resonance Imaging Staging System and Development of a Local Recurrence Risk Stratification Model: The MERCURY II Study. Ann Surg 263, 751-760 (2016).

29. Chand, M., Swift, R. I., Tekkis, P. P., Chau, I. \& Brown, G. Extramural venous invasion is a potential imaging predictive biomarker of neoadjuvant treatment in rectal cancer. Br J Cancer 110, 19-25 (2014).

30. Chand, M. et al. EMVI-positive stage II rectal cancer has similar clinical outcomes as stage III disease following pre-operative chemoradiotherapy. Ann Oncol 25, 858-863 (2014).

31. Chand, M. et al. Adjuvant chemotherapy may improve disease-free survival in patients with mrEMVI-positive rectal cancer following chemoradiation. Colorectal Dis (2016).

32. Chand, M., Moran, B. J., Jones, R. G., Heald, R. J. \& Brown, G. Lymph node status does not predict local recurrence in the total mesorectal excision era. Dis Colon Rectum 57, 127-129 (2014).

33. Chand, M., Heald, R. J. \& Brown, G. The importance of not overstaging mesorectal lymph nodes seen on MRI. Colorectal Dis 15, 1201-1204 (2013).

34. Chand, M. et al. Adjuvant therapy decisions based on magnetic resonance imaging of extramural venous invasion and other prognostic factors in colorectal cancer. Ann R Coll Surg Engl 96, 543-546 (2014). 
35. Quirke, P. et al. Effect of the plane of surgery achieved on local recurrence in patients with operable rectal cancer: a prospective study using data from the MRC CR07 and NCIC-CTG CO16 randomised clinical trial. Lancet 373, 821828 (2009).

36. Cercek, A. et al. Adoption of Total Neoadjuvant Therapy for Locally Advanced Rectal Cancer. JAMA Oncol 4, e180071 (2018).

37. Glynne-Jones, R., Grainger, J., Harrison, M., Ostler, P. \& Makris, A. Neoadjuvant chemotherapy prior to preoperative chemoradiation or radiation in rectal cancer: should we be more cautious. Br J Cancer 94, 363-371 (2006).

38. Garcia-Aguilar, J. et al. Effect of adding mFOLFOX6 after neoadjuvant chemoradiation in locally advanced rectal cancer: a multicentre, phase 2 trial. Lancet Oncol 16, 957-966 (2015).

39. Ngan, S. Y. et al. Randomized trial of short-course radiotherapy versus longcourse chemoradiation comparing rates of local recurrence in patients with T3 rectal cancer: Trans-Tasman Radiation Oncology Group trial 01.04. J Clin Oncol 30, 3827-3833 (2012).

40. Monson, J. R. et al. Practice parameters for the management of rectal cancer (revised). Dis Colon Rectum 56, 535-550 (2013).

41. NCCN Clinical Practice Guidelines in Oncology (NCCN Guidelines®). Rectal Cancer, Version 3.2017. (2017).

42. Fernandez-Martos, C. et al. Chemoradiation, surgery and adjuvant chemotherapy versus induction chemotherapy followed by chemoradiation and surgery: long-term results of the Spanish GCR-3 phase II randomized trial $\uparrow$. Ann Oncol 26, 1722-1728 (2015).

43. Wright, M. E., Beaty, J. S., Thorson, A. G., Rojas, R. \& Ternent, C. A. CostEffectiveness Analysis of Total Neoadjuvant Therapy Followed by Radical Resection Versus Conventional Therapy for Locally Advanced Rectal Cancer. Dis Colon Rectum 62, 568-578 (2019).

44. Patel, U. B. et al. Magnetic resonance imaging-detected tumor response for locally advanced rectal cancer predicts survival outcomes: MERCURY experience. J Clin Oncol 29, 3753-3760 (2011).

45. MERCURY, S. G. Diagnostic accuracy of preoperative magnetic resonance imaging in predicting curative resection of rectal cancer: prospective observational study. BMJ 333, 779 (2006).

46. Beets-Tan, R. G. \& Beets, G. L. MRI for assessing and predicting response to neoadjuvant treatment in rectal cancer. Nat Rev Gastroenterol Hepatol 11, 480488 (2014).

47. Habr-Gama, A. et al. Operative versus nonoperative treatment for stage 0 distal rectal cancer following chemoradiation therapy: long-term results. Ann Surg 240, 711-7; discussion 717 (2004).

48. Habr-Gama, A. et al. Complete clinical response after neoadjuvant chemoradiation therapy for distal rectal cancer: characterization of clinical and endoscopic findings for standardization. Dis Colon Rectum 53, 1692-1698 (2010).

49. Habr-Gama, A. et al. Organ Preservation in cT2N0 Rectal Cancer After Neoadjuvant Chemoradiation Therapy: The Impact of Radiation Therapy Doseescalation and Consolidation Chemotherapy. Ann Surg (2017).

50. Leeds, I. L. \& Fang, S. H. Neoadjuvant Therapy for Rectal Cancer. Dis Colon Rectum 61, 883-886 (2018). 
51. Heald, R. J., Moran, B. J., Ryall, R. D., Sexton, R. \& MacFarlane, J. K. Rectal cancer: the Basingstoke experience of total mesorectal excision, 1978-1997. Arch Surg 133, 894-899 (1998).

52. Chude, G. G. et al. Defunctioning loop ileostomy with low anterior resection for distal rectal cancer: should we make an ileostomy as a routine procedure? A prospective randomized study. Hepatogastroenterology 55, 1562-1567 (2008).

53. Bailey, C. M., Wheeler, J. M., Birks, M. \& Farouk, R. The incidence and causes of permanent stoma after anterior resection. Colorectal Dis 5, 331-334 (2003).

54. Sherman, K. L. \& Wexner, S. D. Considerations in Stoma Reversal. Clin Colon Rectal Surg 30, 172-177 (2017).

55. Seo, S. I. et al. The Role of Diverting Stoma After an Ultra-low Anterior Resection for Rectal Cancer. Ann Coloproctol 29, 66-71 (2013).

56. Nurkin, S., Kakarla, V. R., Ruiz, D. E., Cance, W. G. \& Tiszenkel, H. I. The role of faecal diversion in low rectal cancer: a review of 1791 patients having rectal resection with anastomosis for cancer, with and without a proximal stoma. Colorectal Dis 15, e309-16 (2013).

57. Jayne, D. G. et al. Randomized trial of laparoscopic-assisted resection of colorectal carcinoma: 3-year results of the UK MRC CLASICC Trial Group. $J$ Clin Oncol 25, 3061-3068 (2007).

58. van der Pas, M. H. et al. Laparoscopic versus open surgery for rectal cancer (COLOR II): short-term outcomes of a randomised, phase 3 trial. Lancet Oncol 14, 210-218 (2013).

59. Martling, A. L. et al. Effect of a surgical training programme on outcome of rectal cancer in the County of Stockholm. Stockholm Colorectal Cancer Study Group, Basingstoke Bowel Cancer Research Project. Lancet 356, 93-96 (2000).

60. Wibe, A. et al. A national strategic change in treatment policy for rectal cancer-implementation of total mesorectal excision as routine treatment in Norway. A national audit. Dis Colon Rectum 45, 857-866 (2002).

61. Leroy, J. et al. Laparoscopic total mesorectal excision (TME) for rectal cancer surgery: long-term outcomes. Surg Endosc 18, 281-289 (2004).

62. Kang, S. B. et al. Open versus laparoscopic surgery for mid or low rectal cancer after neoadjuvant chemoradiotherapy (COREAN trial): short-term outcomes of an open-label randomised controlled trial. Lancet Oncol 11, 637-645 (2010).

63. Buunen, M. et al. COLOR II. A randomized clinical trial comparing laparoscopic and open surgery for rectal cancer. Dan Med Bull 56, 89-91 (2009).

64. Stevenson, A. R. et al. Effect of Laparoscopic-Assisted Resection vs Open Resection on Pathological Outcomes in Rectal Cancer: The ALaCaRT Randomized Clinical Trial. JAMA 314, 1356-1363 (2015).

65. Fleshman, J. et al. Effect of Laparoscopic-Assisted Resection vs Open Resection of Stage II or III Rectal Cancer on Pathologic Outcomes: The ACOSOG Z6051 Randomized Clinical Trial. JAMA 314, 1346-1355 (2015).

66. Strong, S. A. \& Soper, N. J. Minimally Invasive Approaches to Rectal Cancer and Diverticulitis: Does Less Mean More. JAMA 314, 1343-1345 (2015).

67. Fleshman, J. et al. Disease-free Survival and Local Recurrence for Laparoscopic Resection Compared With Open Resection of Stage II to III Rectal Cancer: Follow-up Results of the ACOSOG Z6051 Randomized Controlled Trial. Ann Surg (2018).

68. Stevenson, A. R. L. et al. Disease-free Survival and Local Recurrence After Laparoscopic-assisted Resection or Open Resection for Rectal Cancer: The 
Australasian Laparoscopic Cancer of the Rectum Randomized Clinical Trial. Ann Surg (2018).

69. Bianchi, P. P. et al. Robotic versus laparoscopic total mesorectal excision for rectal cancer: a comparative analysis of oncological safety and short-term outcomes. Surg Endosc 24, 2888-2894 (2010).

70. D'Annibale, A. et al. Total mesorectal excision: a comparison of oncological and functional outcomes between robotic and laparoscopic surgery for rectal cancer. Surg Endosc 27, 1887-1895 (2013).

71. Jayne, D. et al. Effect of Robotic-Assisted vs Conventional Laparoscopic Surgery on Risk of Conversion to Open Laparotomy Among Patients Undergoing Resection for Rectal Cancer: The ROLARR Randomized Clinical Trial. JAMA 318, 1569-1580 (2017).

72. Emile, S. H. et al. Evolution of transanal total mesorectal excision for rectal cancer: From top to bottom. World J Gastrointest Surg 10, 28-39 (2018).

73. Sylla, P., Rattner, D. W., Delgado, S. \& Lacy, A. M. NOTES transanal rectal cancer resection using transanal endoscopic microsurgery and laparoscopic assistance. Surg Endosc 24, 1205-1210 (2010).

74. Lacy, A. M. et al. Transanal Total Mesorectal Excision for Rectal Cancer: Outcomes after 140 Patients. J Am Coll Surg 221, 415-423 (2015).

75. Penna, M. et al. Transanal Total Mesorectal Excision: International Registry Results of the First 720 Cases. Ann Surg 266, 111-117 (2017).

76. Atallah, S. et al. Transanal minimally invasive surgery for total mesorectal excision (TAMIS-TME): results and experience with the first 20 patients undergoing curative-intent rectal cancer surgery at a single institution. Tech Coloproctol 18, 473-480 (2014).

77. Burke, J. P. et al. Transanal Total Mesorectal Excision for Rectal Cancer: early outcomes in 50 consecutive patients. Colorectal Dis (2016).

78. Caycedo-Marulanda, A., Jiang, H. Y. \& Kohtakangas, E. L. Outcomes of a Single Surgeon-Based Transanal-Total Mesorectal Excision (TATME) for Rectal Cancer. J Gastrointest Cancer (2017).

79. de Lacy, F. B. et al. Transanal total mesorectal excision: pathological results of 186 patients with mid and low rectal cancer. Surg Endosc (2017).

80. Ma, B. et al. Transanal total mesorectal excision (taTME) for rectal cancer: a systematic review and meta-analysis of oncological and perioperative outcomes compared with laparoscopic total mesorectal excision. BMC Cancer 16, 380 (2016).

81. Muratore, A., Mellano, A., Marsanic, P. \& De Simone, M. Transanal total mesorectal excision (taTME) for cancer located in the lower rectum: short- and mid-term results. Eur J Surg Oncol 41, 478-483 (2015).

82. Motson, R. W., Whiteford, M. H., Hompes, R., Albert, M. \& Miles, W. F. Current status of trans-anal total mesorectal excision (TaTME) following the Second International Consensus Conference. Colorectal Dis 18, 13-18 (2016).

83. Penna, M., Hompes, R., Mackenzie, H., Carter, F. \& Francis, N. K. First international training and assessment consensus workshop on transanal total mesorectal excision (taTME). Tech Coloproctol (2016).

84. Francis, N. et al. Consensus on structured training curriculum for transanal total mesorectal excision (TaTME). Surg Endosc 31, 2711-2719 (2017).

85. Clancy, C., Burke, J. P., Albert, M. R., O’Connell, P. R. \& Winter, D. C. Transanal endoscopic microsurgery versus standard transanal excision for the 
removal of rectal neoplasms: a systematic review and meta-analysis. Dis Colon Rectum 58, 254-261 (2015).

86. Martin-Perez, B., Andrade-Ribeiro, G. D., Hunter, L. \& Atallah, S. A systematic review of transanal minimally invasive surgery (TAMIS) from 2010 to 2013. Tech Coloproctol 18, 775-788 (2014).

87. Kidane, B., Chadi, S. A., Kanters, S., Colquhoun, P. H. \& Ott, M. C. Local resection compared with radical resection in the treatment of T1N0M0 rectal adenocarcinoma: a systematic review and meta-analysis. Dis Colon Rectum 58, 122-140 (2015).

88. You, Y. N., Baxter, N. N., Stewart, A. \& Nelson, H. Is the increasing rate of local excision for stage I rectal cancer in the United States justified?: a nationwide cohort study from the National Cancer Database. Ann Surg 245, 726733 (2007).

89. Stitzenberg, K. B., Sanoff, H. K., Penn, D. C., Meyers, M. O. \& Tepper, J. E. Practice patterns and long-term survival for early-stage rectal cancer. J Clin Oncol 31, 4276-4282 (2013).

90. Paty, P. B. et al. Long-term results of local excision for rectal cancer. Ann Surg 236, 522-29; discussion 529 (2002).

91. Sengupta, S. \& Tjandra, J. J. Local excision of rectal cancer: what is the evidence. Dis Colon Rectum 44, 1345-1361 (2001).

92. Smart, C. J. et al. Multicentre study of short-course radiotherapy and transanal endoscopic microsurgery for early rectal cancer. Br J Surg 103, 1069-1075 (2016).

93. Lezoche, E. et al. Randomized clinical trial of endoluminal locoregional resection versus laparoscopic total mesorectal excision for $\mathrm{T} 2$ rectal cancer after neoadjuvant therapy. Br J Surg 99, 1211-1218 (2012).

94. Garcia-Aguilar, J. et al. Organ preservation for clinical T2N0 distal rectal cancer using neoadjuvant chemoradiotherapy and local excision (ACOSOG Z6041): results of an open-label, single-arm, multi-institutional, phase 2 trial. Lancet Oncol 16, 1537-1546 (2015).

95. Rullier, E. et al. Organ preservation for rectal cancer (GRECCAR 2): a prospective, randomised, open-label, multicentre, phase 3 trial. Lancet (2017).

96. Martens, M. H. et al. Long-term Outcome of an Organ Preservation Program After Neoadjuvant Treatment for Rectal Cancer. J Natl Cancer Inst 108, (2016).

97. Dossa, F., Chesney, T. R., Acuna, S. A. \& Baxter, N. N. A watch-and-wait approach for locally advanced rectal cancer after a clinical complete response following neoadjuvant chemoradiation: a systematic review and meta-analysis. Lancet Gastroenterol Hepatol 2, 501-513 (2017).

98. Dattani, M. et al. Oncological and Survival Outcomes in Watch and Wait Patients With a Clinical Complete Response After Neoadjuvant Chemoradiotherapy for Rectal Cancer: A Systematic Review and Pooled Analysis. Ann Surg 268, 955-967 (2018).

99. Maas, M. et al. Wait-and-see policy for clinical complete responders after chemoradiation for rectal cancer. J Clin Oncol 29, 4633-4640 (2011).

100. Renehan, A. G. et al. Watch-and-wait approach versus surgical resection after chemoradiotherapy for patients with rectal cancer (the OnCoRe project): a propensity-score matched cohort analysis. Lancet Oncol 17, 174-183 (2016).

101. van der Valk, M. J. M. et al. Long-term outcomes of clinical complete responders after neoadjuvant treatment for rectal cancer in the International 
Watch \& Wait Database (IWWD): an international multicentre registry study. Lancet 391, 2537-2545 (2018).

102. Habr-Gama, A. et al. Local recurrence after complete clinical response and watch and wait in rectal cancer after neoadjuvant chemoradiation: impact of salvage therapy on local disease control. Int J Radiat Oncol Biol Phys 88, 822828 (2014).

103. Appelt, A. L., Pløen, J., Vogelius, I. R., Bentzen, S. M. \& Jakobsen, A. Radiation dose-response model for locally advanced rectal cancer after preoperative chemoradiation therapy. Int J Radiat Oncol Biol Phys 85, 74-80 (2013).

104. Habr-Gama, A. et al. Achieving a complete clinical response after neoadjuvant chemoradiation that does not require surgical resection - It may take longer than you think! Dis Colon Rectum In Press, (2019).

105. Parmar, K. L., Malcomson, L. \& Renehan, A. G. Watch and wait or surgery for clinical complete response in rectal cancer: a need to study both sides. Colorectal Dis (2019).

106. Maas, M. et al. Assessment of Clinical Complete Response After Chemoradiation for Rectal Cancer with Digital Rectal Examination, Endoscopy, and MRI: Selection for Organ-Saving Treatment. Ann Surg Oncol 22, 38733880 (2015).

107. Sammour, T., Price, B. A., Krause, K. J. \& Chang, G. J. Nonoperative Management or 'Watch and Wait' for Rectal Cancer with Complete Clinical Response After Neoadjuvant Chemoradiotherapy: A Critical Appraisal. Ann Surg Oncol 24, 1904-1915 (2017).

108. Glynne-Jones, R. et al. Rectal cancer: ESMO Clinical Practice Guidelines for diagnosis, treatment and follow-up. Ann Oncol 29, iv263 (2018).

109. Cancer., A. C. O. S. C. O. The National Accreditation Program for Rectal Cancer Standards Manual. 2017,

110. Bosch, S. L. \& Nagtegaal, I. D. The Importance of the Pathologist's Role in Assessment of the Quality of the Mesorectum. Curr Colorectal Cancer Rep 8, 90-98 (2012).

111. Maslekar, S. et al. Mesorectal grades predict recurrences after curative resection for rectal cancer. Dis Colon Rectum 50, 168-175 (2007).

112. Nagtegaal, I. D. et al. Macroscopic evaluation of rectal cancer resection specimen: clinical significance of the pathologist in quality control. J Clin Oncol 20, 1729-1734 (2002).

113. Kitz, J. et al. Association of Plane of Total Mesorectal Excision With Prognosis of Rectal Cancer: Secondary Analysis of the CAO/ARO/AIO-04 Phase 3 Randomized Clinical Trial. JAMA Surg 153, e181607 (2018).

114. (College of American Pathologists (CAP). Protocol for the Examination of Specimens from Patients with Primary Carcinoma of the Colon and Rectum. Based on AJCC/UICC TNM, 7th edition. ColonRectum 3.1.0.0, (2011).

115. Royal College of Pathologists. Standards and datasets for reporting cancers. Dataset for histopathological reporting of colorectal cancer. Dec 2017. Available onnline at: https://www.rcpath.org/uploads/assets/c8b61ba0-ae3f-43f185ffd3ab9f17cfe6/G049-Dataset-for-histopathological-reporting-of-colorectalcancer.pdf.

116. Nagtegaal, I. D. \& Quirke, P. What is the role for the circumferential margin in the modern treatment of rectal cancer. J Clin Oncol 26, 303-312 (2008). 
117. Glynne-Jones, R., Mawdsley, S. \& Novell, J. R. The clinical significance of the circumferential resection margin following preoperative pelvic chemoradiotherapy in rectal cancer: why we need a common language. Colorectal Dis 8, 800-807 (2006).

118. Hong, K. S., Moon, N., Chung, S. S., Lee, R. A. \& Kim, K. H. Oncologic outcomes in rectal cancer with close distal resection margins: a retrospective analysis. Ann Surg Treat Res 89, 23-29 (2015).

119. Persiani, R. et al. Prognostic implications of the lymph node count after neoadjuvant treatment for rectal cancer. Br J Surg 101, 133-142 (2014).

120. Rullier, A. et al. Lymph nodes after preoperative chemoradiotherapy for rectal carcinoma: number, status, and impact on survival. Am J Surg Pathol 32, 45-50 (2008).

121. Awwad, G. E., Tou, S. I. \& Rieger, N. A. Prognostic significance of lymph node yield after long-course preoperative radiotherapy in patients with rectal cancer: a systematic review. Colorectal Dis 15, 394-403 (2013).

122. Chang, G. J., Rodriguez-Bigas, M. A., Eng, C. \& Skibber, J. M. Lymph node status after neoadjuvant radiotherapy for rectal cancer is a biologic predictor of outcome. Cancer 115, 5432-5440 (2009).

123. Berman, H. L. The tumor board: is it worth saving. Mil Med 140, 529-531 (1975).

124. Calman K, H. D. A Policy Framework for Commissioning Cancer Services. London: Department of Health; 1995.

125. Berrino, F. et al. Survival for eight major cancers and all cancers combined for European adults diagnosed in 1995-99: results of the EUROCARE-4 study. Lancet Oncol 8, 773-783 (2007).

126. Dietz, D. W, Consortium, for Optimizing Surgical Treatment of Rectal Cancer (OSTRiCh). Multidisciplinary management of rectal cancer: the OSTRICH. $J$ Gastrointest Surg 17, 1863-1868 (2013.)

127. Monson, J. R. et al. Failure of evidence-based cancer care in the United States: the association between rectal cancer treatment, cancer center volume, and geography. Ann Surg 260, 625-31; discussion 631 (2014).

128. van Leeuwen, A. F., Voogt, E., Visser, A., van der Rijt, C. C. \& van der Heide, A. Considerations of healthcare professionals in medical decision-making about treatment for clinical end-stage cancer patients. J Pain Symptom Manage 28, 351-355 (2004).

129. Patkar, V. et al. Cancer multidisciplinary team meetings: evidence, challenges, and the role of clinical decision support technology. Int J Breast Cancer 2011, 831605 (2011).

130. National Institute for Clinical Excellence (NICE). Improving Outcomes in Colorectal Cancers: Manual Update. London. (2004)..

131. Rickles, A. S. et al. High Rate of Positive Circumferential Resection Margins Following Rectal Cancer Surgery: A Call to Action. Ann Surg 262, 891-898 (2015).

132. Patel, A., Franko, E. R. \& Fleshman, J. W. Utilizing the multidisciplinary team for planning and monitoring care and quality improvement. Clin Colon Rectal Surg 28, 12-20 (2015).

133. An international, multidisciplinary approach to the management of advanced colorectal cancer. The International Working Group in Colorectal Cancer. Eur J Surg Oncol 23 Suppl A, 1-66 (1997). 
134. Jessop J, D. I. in Challenges in Colorectal Cancer, 2nd ed. (ed Scholefield JH, A. H., Maughan T.) 167-177 (Blackwell, Oxford, 2006).

135. Richardson, B. et al. The effect of multidisciplinary teams for rectal cancer on delivery of care and patient outcome: has the use of multidisciplinary teams for rectal cancer affected the utilization of available resources, proportion of patients meeting the standard of care, and does this translate into changes in patient outcome. Am J Surg 211, 46-52 (2016).

136. Swellengrebel, H. A. et al. Multidisciplinary discussion and management of rectal cancer: a population-based study. World J Surg 35, 2125-2133 (2011).

137. Brännström, F. et al. Multidisciplinary team conferences promote treatment according to guidelines in rectal cancer. Acta Oncol 54, 447-453 (2015).

138. Verdecchia, A. et al. Survival trends in European cancer patients diagnosed from 1988 to 1999. Eur J Cancer 45, 1042-1066 (2009).

139. Wille-Jørgensen, P. et al. Result of the implementation of multidisciplinary teams in rectal cancer. Colorectal Dis 15, 410-413 (2013).

140. Munro, A., Brown, M., Niblock, P., Steele, R. \& Carey, F. Do Multidisciplinary Team (MDT) processes influence survival in patients with colorectal cancer? A population-based experience. BMC Cancer 15, 686 (2015).

141. Taylor, C. et al. Multidisciplinary team working in cancer: what is the evidence. BMJ 340, c951 (2010).

142. El Saghir, N. S. et al. Global Practice and Efficiency of Multidisciplinary Tumor Boards: Results of an American Society of Clinical Oncology International Survey. J Glob Oncol 1, 57-64 (2015).

143. Ugwumadu, L. et al. The role of the multidisciplinary team in the management of deep infiltrating endometriosis. Gynecol Surg 14, 15 (2017).

144. Berho, M., Narang, R., Van Koughnett, J. A. \& Wexner, S. D. Modern multidisciplinary perioperative management of rectal cancer. JAMA Surg 150, 260-266 (2015).

145. Wexner, S. D. \& Berho, M. E. The Rationale for and Reality of the New National Accreditation Program for Rectal Cancer. Dis Colon Rectum 60, 595602 (2017).

146. Improved survival with preoperative radiotherapy in resectable rectal cancer. Swedish Rectal Cancer Trial. N Engl J Med 336, 980-987 (1997).

147. Kapiteijn, E. et al. Preoperative radiotherapy combined with total mesorectal excision for resectable rectal cancer. N Engl J Med 345, 638-646 (2001).

148. Sauer, R. et al. Preoperative versus postoperative chemoradiotherapy for rectal cancer. N Engl J Med 351, 1731-1740 (2004).

149. Bosset, J. F. et al. Chemotherapy with preoperative radiotherapy in rectal cancer. N Engl J Med 355, 1114-1123 (2006).

150. Hong, Y. S. et al. Oxaliplatin, fluorouracil, and leucovorin versus fluorouracil and leucovorin as adjuvant chemotherapy for locally advanced rectal cancer after preoperative chemoradiotherapy (ADORE): an open-label, multicentre, phase 2, randomised controlled trial. Lancet Oncol 15, 1245-1253 (2014).

151. Rödel, C. et al. Oxaliplatin added to fluorouracil-based preoperative chemoradiotherapy and postoperative chemotherapy of locally advanced rectal cancer (the German CAO/ARO/AIO-04 study): final results of the multicentre, open-label, randomised, phase 3 trial. Lancet Oncol 16, 979-989 (2015).

152. Guillou, P. J. et al. Short-term endpoints of conventional versus laparoscopicassisted surgery in patients with colorectal cancer (MRC CLASICC trial): multicentre, randomised controlled trial. Lancet 365, 1718-1726 (2005). 
153. Laurent, C., Leblanc, F., Wutrich, P., Scheffler, M. \& Rullier, E. Laparoscopic versus open surgery for rectal cancer: long-term oncologic results. Ann Surg 250, 54-61 (2009).

154. Lujan, J. et al. The learning curve of laparoscopic treatment of rectal cancer does not increase morbidity. Cir Esp 92, 485-490 (2014).

155. Segelman, J., Singnomklao, T., Hellborg, H. \& Martling, A. Differences in multidisciplinary team assessment and treatment between patients with stage IV colon and rectal cancer. Colorectal Dis 11, 768-774 (2009).

156. Lordan, J. T., Karanjia, N. D., Quiney, N., Fawcett, W. J. \& Worthington, T. R. A 10-year study of outcome following hepatic resection for colorectal liver metastases - The effect of evaluation in a multidisciplinary team setting. Eur $J$ Surg Oncol 35, 302-306 (2009).

157. MacDermid, E. et al. Improving patient survival with the colorectal cancer multi-disciplinary team. Colorectal Dis 11, 291-295 (2009).

158. Palmer, G., Martling, A., Cedermark, B. \& Holm, T. Preoperative tumour staging with multidisciplinary team assessment improves the outcome in locally advanced primary rectal cancer. Colorectal Dis 13, 1361-1369 (2011).

159. Du, C. Z. et al. Effect of multidisciplinary team treatment on outcomes of patients with gastrointestinal malignancy. World J Gastroenterol 17, 2013-2018 (2011).

160. Ye, Y. J. et al. Impact of multidisciplinary team working on the management of colorectal cancer. Chin Med J (Engl) 125, 172-177 (2012).

161. Levine, R. A., Chawla, B., Bergeron, S. \& Wasvary, H. Multidisciplinary management of colorectal cancer enhances access to multimodal therapy and compliance with National Comprehensive Cancer Network (NCCN) guidelines. Int J Colorectal Dis 27, 1531-1538 (2012).

162. Prades, J., Remue, E., van Hoof, E. \& Borras, J. M. Is it worth reorganising cancer services on the basis of multidisciplinary teams (MDTs)? A systematic review of the objectives and organisation of MDTs and their impact on patient outcomes. Health Policy 119, 464-474 (2015).

\section{Competing interests}

The authors declare no competing interests

\section{Author contributions}

All authors contributed equally to aspects of this manuscript. 